\title{
Political Instability: Effects on Financial Development, Roots in the Severity of Economic Inequality
}

\section{Citation}

Mark J. Roe \& Jordan Siegel, Political Instability: Effects on Financial Development, Roots in the Severity of Economic Inequality, 39 J. Comp. Econ. 279 (2011).

\section{Published Version}

http://ac.els-cdn.com/S014759671100014X/1-s2.0-S014759671100014X-main.pdf?

_tid=3beecd32-0b45-11e3-9f52-00000aab0f02\&acdnat=1377187953_62d8944077eacfe4bc5c197bb2633c22

\section{Permanent link}

http://nrs.harvard.edu/urn-3:HUL.InstRepos:12019047

\section{Terms of Use}

This article was downloaded from Harvard University's DASH repository, and is made available under the terms and conditions applicable to Open Access Policy Articles, as set forth at http:// nrs.harvard.edu/urn-3:HUL.InstRepos:dash.current.terms-of-use\#OAP

\section{Share Your Story}

The Harvard community has made this article openly available.

Please share how this access benefits you. Submit a story.

\section{Accessibility}




\title{
Political instability: Effects on financial development, roots in the severity of economic inequality
}

\author{
Mark J. Roe and Jordan I. Siegel
}

February 3, 2011

\begin{abstract}
We here bring forward strong evidence that political instability impedes financial development, with its variation a primary determinant of differences in financial development around the world. As such, it needs to be added to the short list of major determinants of financial development. First, structural conditions first postulated by Engerman and Sokoloff (2002) as generating long-term inequality are shown here empirically to be exogenous determinants of political instability. Second, that exogenously-determined political instability in turn holds back financial development, even when we control for factors prominent in the last decade's cross-country studies of financial development. The findings indicate that inequality-perpetuating conditions that result in political instability are fundamental roadblocks for international organizations like the World Bank that seek to promote financial development. The evidence here includes country fixed effect regressions and an instrumental model inspired by Engerman and Sokoloff's (2002) work, which to our knowledge has not yet been used in finance and which is consistent with current tests as valid instruments. Four conventional measures of national political instability Alesina and Perotti's (1996) well-known index of instability, a subsequent index derived from Banks' (2005) work, and two indices of managerial perceptions of nation-by-nation political instability - persistently predict a wide range of national financial development outcomes for recent decades. Political instability's significance is time consistent in cross-sectional regressions back to the 1960's, the period when the key data becomes available, robust in both country fixed-effects and instrumental variable regressions, and consistent across multiple measures of instability and of financial development. Overall, the results indicate the existence of an important channel running from structural inequality to political instability, principally in nondemocratic settings, and then to financial backwardness. The robust significance of that channel extends existing work demonstrating the importance of political economy explanations for financial development and financial backwardness. It should help to better understand which policies will work for financial development, because political instability has causes, cures, and effects quite distinct from those of many of the key institutions most studied in the past decade as explaining financial backwardness.
\end{abstract}

${ }^{*}$ Harvard University, mroe@law.harvard.edu and jsiegel@hbs.edu. We thank Harvard Business School's Division of Research and Harvard Law School's John Olin Center for Law, Economics, and Business for research support. For comments we thank panelists at the Academy of Management and the annual finance meetings of the American Economics Association, participants in workshops at Cambridge, Columbia, Harvard, the London School of Economics, Oxford, the Sorbonne, Queen's University, the University of Hong Kong, the University of Tokyo, the University of Vienna, and the University of Zürich, the editor, and the referees. 
Electronic copy available at: http://ssrn.com/abstract=963214 


\title{
Political instability: Effects on financial development, roots in the severity of economic inequality
}

\author{
Mark J. Roe and Jordan I. Siegel
}

\section{INTRODUCTION}

Financial development is widely seen as necessary or useful to propel economic growth, to create wealth, and to develop a nation (Levine (1997); King and Levine (1993); Sylla et al. (1999); Rajan and Zingales (1998, 2003, 2003b); Mishkin (2006: 25)). This view has become conventional wisdom and has induced international agencies and development officials to bolster financial markets by strengthening their supporting institutions, particularly via institutions of investor protection, in the hope that economic development will quickly follow, as the World Bank's (2006) report reflects.

Despite efforts to develop finance and its associated institutions, financial development around the world has been uneven, with prominent explanations for its variation tied to a nation's corporate and securities law institutions, its legal origin, its trade openness, and its legacy of colonial endowments. The unevenness of financial development provides reason to search for other important determinants of, and impediments to, financial development beyond those found significant in the past decade. Other factors could also explain differences in financial development. Findings in adjacent disciplines suggest that political instability strongly affects overall economic development. That instability, which is often rooted in severe economic inequality, could affect financial development as well and could do so independently of its effect on overall economic development. And we indeed find that political stability and the fundamental conditions that induce it should be added to our understanding of the key determinants of modern financial development.

Engerman and Sokoloff (2002) postulated that historical conditions, often due to agricultural necessity in the colonial era, could induce economic inequality and institutional structures that could persist to today. Our results here point to such conditions as perpetuating economic inequality as having an exogenous impact on political instability, which in turn holds back the financial development of 
countries. And they point there, significantly, even when countries take on the predicted value proposed in prior work for explaining financial backwardness.

We construct an instrumental variable model with these concepts in mind, one yielding significant results and one where the proposed instrumental variables are consistent with current tests of theoretical and empirical validity. The inequality-to-instability-to-weak-finance results are also robust to the use of country fixed effects and consistent in year-by-year cross-sectional regressions. Methodologically, the findings here, as far as we can ascertain, represent one of the few empirical cross-country studies of financial development to incorporate both instrumental variables and country fixed effects. Overall, our effort provides good evidence for a causal channel leading to financial backwardness that receives too little attention from policymakers and international organizations such as the World Bank. These actors have primarily focused on investor protection during the past decade or two, whereas our results indicate that investor protection cannot have its full desired effect when strong structural economic inequality persists and induces an unstable polity.

The first political instability indicator we use here derives not from the advanced nations' shifting coalitions, Arrow-type policy cycling, or swings in elections, governments, or policy, but instead derives from the severe, sharp disorder that nations, usually less developed nondemocratic ones, suffer via military coups, irregular changes in government, and political violence. The second derives from indicators of government crisis. The third and fourth are constructed from managerial perceptions of national political instability. Such instability quite plausibly impedes a nation from building institutions, such as investor protection, that support finance or undermines such institutions' effectiveness even if built. Severe instability such as that measured by the first two indices has been frequent in the past four decades. Cross-country variation in the severity of political disorder powerfully explains much of the variation in financial outcomes around the world in the past forty years. It is robust to prevailing explanations, some of which persist as significant and some of which do not.

A widespread view in the law and finance literature, a view to which we subscribe, sees investor protection institutions to be critical to financial development, as the text and citations below show. E,g., 
La Porta et al. (1998); Dyck and Zingales (2004). But what induces one nation to build adequate investor protection institutions and another not to? Much current thinking in finance looks to a combination of legal origin, trade openness, colonial conditions, and the related and resultant institutions, as the important channels to investor protection. (We discuss this literature below.) Partly as a result of these influential views, the policy advice the World Bank and others give to developing countries focuses foremost on the institutions among these causal factors that can be altered quickly, such as investor protection rules and corporate codes of conduct (World Bank (2006)). Investor protection in this literature is seen as being an institutional choice, one implemented via courts, rules, and regulators.

We add to this work. Primary institutions of investor protection, such as courts, legal rules, and regulators, cannot function well in unstable political environments and this inability may be a critical channel connecting political instability to financial backwardness. A country's capacity and willingness to build and maintain investor protection, as well as other property protection, institutions depend largely on its relative political stability. Unstable polities cannot, or will not, reliably protect investors. Even if conventional institutions of investor protection are in place, there is reason to expect them to be ineffective in highly unstable polities.

This political instability channel to financial backwardness leads back to more. When we observe that a dominant root of political instability uncovered in the political economy literature in weak democracies is the severity of economic inequality, we unearth a deeper explanation for a polity's incapacity and unwillingness to protect investors, one that becomes clear as we place the pieces next to one another: when inequality is severe, investor protection protects favored strata in those unstable nations. But protecting those favored strata is something an unstable polity mired in severe inequality cannot do easily. We present strong evidence for this political economy characteristic being a major channel explaining financial backwardness, one that could explain why some nations cannot, or will not, build the needed institutions and why they work badly in some nations even when built.

If separate channels run through or from political instability and exercise a first-order impact on financial development, then differently prioritized policy considerations could come into play. If other 
sources of political instability are not associated with the currently-prominent channels, such as building up investor protection (or pulling down trade barriers), then further protecting investors (or further opening up trade) could fail to sufficiently foster finance. Although they are policies that could improve economic conditions, in an unstable polity they could fail to have their intended effect. Such efforts could fail because the independently unstable polity could undo whatever benefits better investor protection provided in developing finance. We seek in this article to understand whether this independence is plausible, conclude that there is strong evidence that it is, and raise the question as to whether its plausibility helps to explain why finance has progressed unevenly around the world.

Conventional policy advice could backfire if independent channels run from political instability to financial backwardness, because an investor-protection-oriented policy focus could fail if other political foundations must be built simultaneously. That result could sour policy-makers on protection tools, when they are in fact necessary, but insufficient. Indeed, in some national settings in the developing world, further protecting investors could further destabilize an already unstable polity. Given Alesina and Perotti's (1996) finding that severe economic inequality is the key determinant of political instability and given the likelihood that investor protection would protect the most favored elements in such polities, this risk of backfire, although speculative, is plausible. More specifically, investor protection may fail to function well in polities that fail to first develop sufficient equality, such as that of a broad, propertyowning middle-class.

Causality considerations and the possibility of collinearity are relevant but do not erase the lines running from political instability in general and inequality-induced instability in particular. First, instability is not strongly collinear with prior explanatory variables. Second, variance inflation factor analysis shows that no significant multicollinearity influences the models. Third, to anchor causality as running from instability to financial outcomes, we deploy a two-stage instrumental variable model, with instruments inspired by Engerman and Sokoloff's (2002) general work on economic development. As far as we are aware, such instruments have not previously been used in analyzing financial development. Key institutions needed for basic financial development would function poorly in a severely unstable polity, 
making it odd if finance developed strongly while the polity was unstable and if financial development thereafter stabilized that polity. Both the two-stage evidence and prior law and finance theory fit best with a key causal channel running from political instability to financial backwardness.

Achieving a stable polity is a first order societal economic problem. Our empirical approach shows a direct channel from instability to financial and economic weakness, one that swamps the legal variables that are thought important to financial development. To note that financial disruptions in a previously stable polity could induce political instability, as recent disruptions in Greece and elsewhere suggest, does not undermine the evidence here that a major, although not exclusive channel oftentimes runs from instability to financial backwardness. And, via both fixed effects and instrumental variables that have not yet been widely deployed in the financial development literature, we show strong evidence for an important indirect channel over time that runs through weakened institutional supports for finance, institutions that political instability renders difficult, weak, or nonexistent in a polity.

Simply showing that political instability diminished financial development could be secondary for understanding financial development if instability's effect on finance were only channeled through its effect on economic development and if nations quickly returned to their prior financial development path after a short bout of instability. But it appears not to be limited only to a channel through its impact on economic development: when we control for economic development, via both the log of per capita GDP and GDP growth rates, political instability's significance persists in our models, statistically and economically. These results point to instability operating on finance directly, presumably through an institutional channel, and not solely indirectly through its effects on economic development generally. Accordingly, our results are consistent with Engerman and Sokoloff's (2002) general approach to economic development, when applied to financial development. And, lastly, we re-run our primary models with political instability reconfigured as a decay index, yielding results indicating a continuing drag on financial development from prior instability.

Moreover, it is potentially important to understand the relative importance of ongoing political instability and the institutional features that have been prominent in the economic literature in the recent 
decade. If political instability is a dominating influence, year after year, regardless of the strength or weakness of institutional capacity, then there could be bases to reassess development strategies. An analogue via metaphor comes to mind: health authorities can focus on properly inoculating populations against disease. This is valuable, but health authorities also need to assess whether a more fundamental problem is coming from a large fraction of a population being inability to get close to the needed 2000 calorie intake daily. We assess the latter, without disparaging efforts to improve the former. Four decades of year-by-year regressions and country fixed-effects regressions show a regular and powerful correlation between political stability and strong financial development on the one hand and political instability and weak financial development on the other. Results are similar for political instability's association with weak financial outcomes in the less developed, non-OECD subsample.

Our work here relates to La Porta et al. $(1997,1998,2008)$ in searching for the bases for financial development, although we find current political instability to explain financial development more powerfully than historical legal origin. It relates to Alesina and Perotti (1996) in that it finds political instability to be a primary determinant of an economic outcome. It especially relates to Engerman and Sokoloff (2002), and Acemoglu, Johnson, and Robinson's (2001) closely related work, in finding inequality, political instability, and institutional quality interacting to produce economic outcomes, in our case financial backwardness.

Our work here also complements promising recent related political economy explanations for finance. These complementary explanations, however, often focus primarily, and sometimes exclusively, on developed democracies, while our work largely seeks to understand financial development in less developed nations. Rajan and Zingales (2003) examine how industrial elites repressed finance to undermine their potential product market competitors, especially during the first part of the twentieth century, while we focus on how conflict between the elites and others, when severe enough, destabilizes a polity and undermines financial development. Perotti and von Thadden (2005) and Perotti and Schwienbacher (2009) focus on the median voter in richer democracies. Where the median voter has lost his or her financial assets in, say, the interwar inflation in Europe, but has strong human capital, the 
median voter will prefer industrial stability, without the disruptions that securities markets bring. Pagano and Volpin (2005) and Gourevitch and Shinn (2005), the latter from the political science literature, argue that shifting coalitions among managers, employees and shareholders can explain the degree to which a polity will provide shareholder protection. Roe (2000, 2003), from the legal literature, argues that for Western Europe and East Asia in the first post-War decades, the severity and nature of left-right conflict, and the effort to co-opt internal left-oriented groups and political parties, explain core financial differences in the post-World War II decades among the richer capitalist democracies. When labor power makes strong claims on firm's cash flows, he argues, concentrated owners have a comparative advantage over dispersed owners in forming a countervailing coalition. Nations with strong left power after World War II, governments were less likely to support the capital markets institutions that would protect outside stockholders and bondholders (such as well-funded regulators and business courts).

Although these political economy theories are promising, they have limited relevance for the developing world. They rather could better explain coalitions and institutions in the wealthier, alreadydeveloped nations, explaining why, say, France, Germany, and Italy have had more concentrated ownership and weaker financial markets overall than the United States in the past half-century. Several contrast continental European economies and polities with that of the United States during recent history. These political economy theories explain financial development and backwardness in developing and transition nations less well. Nor do they for the most part purport to explain finance in those nations. Political economy explanations may still be central for poorer, developing democracies and nondemocracies, but they are not likely to be identical to the best political economy explanations for differing structures and depth of financial markets in the wealthy West.

The concept here is both new and old. It is new because we focus more on inequality-induced political variation as impeding financial development and less on the last decade's ideas as to the important institutional foundations for financial development. The impact of inequality-induced political 
instability has not been a major focus for financial development scholarship of the past decade. It is old, because the basic concepts go back through the ages, finding vivid expression in Aristotle's Politics: “the equalization of property ... tend[s] to prevent the citizens from quarreling" (Aristotle (1986: 45, Bk II, Sec. VII). But simply striving for equality in unequal settings is no sure cure, as the striving by itself creates the very conflict that the polity needs to avoid (id: 142-144, Bk V, ch. 1.), yielding no easy recipe for stability. Overall, says Aristotle, "[i]t is ever best to live where equality prevails" (id: 158, Bk V, ch. VII), but not where it is absent and not where the citizenry are striving for it.

We conclude by linking two major literatures: an economics literature that sees political instability as strongly impeding economic development (e.g., Alesina and Perotti (1996); Rodrik (1999)) and a finance literature that sees financial development as strongly propelling economic development. A primary channel from political stability to economic development could well run through financial development. If so, much is at stake both intellectually and for policy-making in knowing whether political instability, which could depend on rough economic equality and the breadth of a propertyowning middle class, is a primary determinant of financial backwardness. Although building such a foundation is far more difficult than building the formal institutions of investor protection - and is beyond the remit of the development agencies — we outline below how further work can integrate the finding into policy.

\section{EXPLAINING FinANCIAL MARKET DEVELOPMENT}

Several explanations have become prominent in explaining financial development: legal origin, colonial endowments, trade openness, and political economy configurations arising from colonial endowments. Common law systems are seen as particularly adept at protecting investors with welldeveloped legal remedies, while civil law nations, particularly French civil law nations, do not, La Porta et al. (1997, 1998) and Beck, Demirgüç-Kunt, and Levine (2001) report. Rajan and Zingales (2003) look at incumbent interests who seek to thwart upstarts by denying them financial opportunities. But when the nations' trade channels are open, the incumbents need new financing as well, so they cease opposing 
financial development. Stulz and Williamson (2003) focus on cultural characteristics. Acemoglu, Johnson, and Robinson (2001) and Engerman and Sokoloff (2002: 88) develop a colonial endowments view, that those colonies that developed via extractive industries or plantation agriculture run by a small, elite group of colonizers using a large, unskilled labor force tended to have weak property rights. In contrast, colonies settled mostly by immigrants from the mother country developed stronger property rights, stronger educational traditions, and stronger financial and economic development. Relative democratic political instability should be added as a central consideration and, as our results show, is robust to the current explanations for differences in financial development, although we confirm the significance of several of the prominent ones.

Consider extreme instability, such as from insurrection, severe domestic violence, assassination, or a destructive civil war. Lindgren (2005: 10-12) reports: "[t]oday most armed conflicts are civil wars... . They accounted for $77 \%$ of armed conflicts [during the years] 1989-2003." Such instability and conflict divert the attention of public officials; capital flees the country; skilled people emigrate; and the base for economic and financial development weakens. Entrepreneurs who remain are unwilling to invest in physical assets and need less finance. "In this risky environment many entrepreneurs ... engage [only] in economic pursuits that yield fast and large returns ... " Lindgren (2005: 5) states. Short-term investments need less sophisticated capital market institutions than long-term investments. Unstable governments can provide and maintain the machinery of contract enforcement and property protection only with difficulty. Governmental macro- and financial policies and opportunities weaken. ${ }^{1}$

Two observations are worth keeping in mind. First, the incidence of serious, violent political instability has simply not been small. Fifty-seven countries had three or more instances of severe political instability, even short of civil war, since the 1980s, Banks (2005) reports. Second, there is a simple and strong association between political instability and financial outcomes, one that Figure 1 illustrates.

\footnotetext{
${ }^{1}$ Acemoglu et al. (2003) links poor macroeconomic policy to a weak institutional environment. Outreville (1999), in an unpublished paper, presents cross-sectional results linking Alesina and Perotti's (1996) instability index to the size of the money supply (M2). His result was limited to the late 1980s and did not control for legal institutions, trade openness, or colonial conditions, but is encouraging for our study.
} 
Hence, there is reason to measure modern political instability, see if it predicts financial outcomes, examine the basic causes posited, such as severe economic inequality, and determine its robustness to alternative explanations for the world's variation in financial development.

\section{DATA DESCRIPTION}

We measure political instability's effects on financial markets across time and across nations. To do so, we need measures of political stability and measures of financial market outcomes. Four major indices of political stability are available. One is from Alesina and Perotti (1996), another from Banks (2005). For more recent years, a third is available from the Lausanne-based IMD (International Institute of Managerial Development) World Competitiveness Yearbook (1999-2004) and a fourth from the World Economic Forum. We use four instability indices not just to see if the results persist over different measures, but because the indices cover different time periods and we want to see if our results persist over time. There are multiple ways to measure financial development, so we use multiple indicators. The results prevail across the multiple indicators.

\section{A. Measures of Political Stability}

The first instability measure here is Alesina and Perotti's (1996: 1207-1208) sociopolitical instability (SPI) index, which measures the average political instability by country during the 1960-1982 period. Using principal component analysis, they construct their index from data on a nation's number of politically-motivated assassinations, the number of people killed in domestic mass violence (as a percentage of the nation's total population), the number of successful and attempted coups, and a categorical variable for whether the nation is a democracy or a dictatorship. Because the index uses deep disruptions — such as military coups and political assassinations — simple electoral change, even if frequent and sharp, does not count as unstable; violent change, even if infrequent, does. Because they weight the index with a categorical indicator of democracy, their index is not purely one of political instability in its intuitive sense. Pinochet's Chile, for example, would be stable in an intuitive sense, but, due to the democracy measure and the prevalence of violence, it is not coded as highly stable in the 
Alesina-Perotti index. (The categorical democracy variable could capture some expected probability of future disruptions.) As such, the index could be recast as one of democratic political regularity. Regardless, this has been a respected and widely used measure - cited more than 100 times in the academic literature - of political instability, or as we might rename it, of democratic political regularity.

Alesina and Perotti (1996) show that the SPI index predicted total public and private sector investment by country during the years 1960-1985 and we follow them in testing whether the SPI index predicts private debt and equity market development. However, the data from which Alesina and Perotti derive their index was only collected through 1982 (Taylor and Jodice (1983)). ${ }^{2}$ Accordingly, it is of limited use for assessing the political instability's potential impact in more recent years. Because of this time limit to the index, and so as not to rely on just one measure of political crisis, we build our own subsequent index with the Cross-National Time Series (CNTS) database that Banks (2005) compiled of later political instability. This database, an earlier version of which served as the basis of Barro-Lee's (1994) political instability measures, has instability data running through 2003 . We focus on its "government crisis" variable and, to better see whether past instability has continuing effect, we generate a moving index of political instability. ${ }^{3}$ We take data on government crises by year for each country and use a 1 percent decay rate for assessing the impact of past government crises over the prior 30-year period. To check the robustness of the 1 percent decay rate, we ran the same tests with a 5 percent and a 10 percent decay rate with varying time periods. Results with these were similar to those with the 1 percent rate.

A third measure of political instability comes from IMD's World Competitiveness Yearbook (WCY). Since 1999, the WCY reported how several thousand executives around the world ranked political instability country-by-country, with the surveyed executives asked to rate on a scale of $0-10$ the

\footnotetext{
${ }^{2}$ We reconstructed and confirmed the Alesina-Perotti index from its components; the reconstruction, with the slightly varying index for democracy available to us, had a correlation approaching 1.00.

${ }^{3}$ Because the most serious forms of political violence (as shown both in Banks' data and illustrated in Figures 4 and 5) declined in recent years, Banks' government crisis variable stood out as plausibly explaining the instability component to recent financial development in the developing world. It included major eruptions of major political violence up to but not including coups. In the post-1980 environment, the incidence of coups and civil wars declined, resulting in low variation in these variables such that they no longer explained differences in financial development. However, severe political instability up to but not
} 
extent to which they agree with the statement that, for their home country, "the risk of political instability is very low." The IMD's annual results were averaged over the 1999-2003 and 1999-2004 periods that overlap with our financial development indicators. The IMD index has the advantages of measuring business world actors' perceptions of political instability and of focusing on recent years. We also use a similar executive survey from the World Economic Forum's Global Competitiveness Report, which asks executives in a country the likelihood of legal and political stability over the subsequent five years.

\section{B. Measures of Financial Outcomes}

The main outcomes we use are stock market depth and banking breadth, as measured by stock market capitalization/GDP and bank loans/GDP, two core indicators of a nation's financial depth. Perhaps because they are core indicators, better data is available for more countries and more years than for other indicators.

For debt markets, the World Bank's World Development Indicators (WDI) data on the amount of bank credit divided by GDP is the starting measure. ${ }^{4}$ We also use a closely related WDI measure of the total amount of credit received by the private sector divided by GDP. ${ }^{5}$ Both measures are available in the WDI June 2006 release for years 1965-2004. Next, from a 2006 update of a publicly available database that Beck, Demirgüç-Kunt, and Levine (2000) compiled, we use their variable for the size of the private bond market divided by GDP, as well as their variable for the size of the public bond market divided by GDP. ${ }^{6}$ Those last two variables are available for years 1990-2003.

For equity markets, we first focus on stock market capitalization divided by GDP and the number of listed firms per thousands in population, two equity market variables available from WDI for years

including coups and civil wars continued to be widespread and variation on this measure proved highly significant in explaining ongoing equity market development.

${ }^{4}$ Formally: Domestic credit provided by the banking sector as a percentage of GDP. The WDI bank credit/GDP number includes the banks' credit position in relation to government-owned firms and government entities. The data is available starting in 1965, allowing us to regress bank credit/GDP on political instability over four decades.

${ }^{5}$ Formally: Domestic credit to the private sector, as a percentage of GDP. It includes all credit in which the private sector is the recipient.

${ }^{6}$ This Year 2006 data release came from http://www.econ.brown.edu/fac/Ross_Levine/Publications.html. This data goes back to 1976, enabling a 3-decade long series of year-by-year regressions of stock market capitalization on political instability. We understand that the pre-1988 raw data on stock market capitalization came from the S\&P Global Stock Markets Factbook (available at http://www.standardandpoors.com/products-services/global-stock-markets-factbook/en/us) and the Emerging Markets Data Base. 
1988-2004. Next, from the 2006 release of the database Beck, Demirgüç-Kunt, and Levine (2000) compiled, we use their coding of the variable for stock market capitalization divided by GDP. The latter data is available for a larger number of years (1976-2003), allowing us to see whether the effects persist year-by-year over more than a quarter of a century.

For the other independent variables and for the controls, we use legal origin, trade openness, latitude, governmental structure, and per capita income. Table 1 lists the variables and their sources; Table 2 summarizes the data.

\section{Further Data}

Because we are also although secondarily interested in identifying plausible causes of political instability in addition to its effects, we examine income inequality, the variable that Alesina and Perotti (1996) use to predict political instability. The relative proportion of national income going to the middle class (defined as the third and fourth quintiles) comes from Perotti (1996) for 1960 or the closest annual observation available after 1960. We supplement that data with measures of Gini coefficients in the WIDER World Income Inequality Database for years $1970-2000 .^{7}$ Following the WIDER database compilers' recommendation, we focus on the Gini measures they rated as highest quality and chose those observations closest to each decade point (1970, 1980, 1990, and 2000).

Ethnic fractionalization is the most prominent further explanation for political instability, although even its explanatory power often comes from how it facilitates economic inequality (by exacerbating a dominant group's propensity to deny wealth to poorer citizens from another ethnic group). We use Alesina, Devleeschauwer, Easterly, Kurlat, and Wacziarg's (2003) measures of ethnic fractionalization.

To control for trade openness, we follow Rajan and Zingales (2003) in using the measure of natural geographic openness that Frankel and Romer (1999) created (and called "constructed trade share") and that Rajan and Zingales then used in the finance literature. We also use other measures of trade openness — [imports plus exports]/GDP and [imports plus exports]/GDP instrumented by constructed trade share.

\footnotetext{
${ }^{7}$ The WIDER database can be accessed at http://www.wider.unu.edu/wiid/wiid.html.
} 
(Our political instability results below are robust to both, although trade openness is itself typically significant, as in Rajan and Zingales (2003).)

Because some authors believe that close-to-the-equator latitude drove most negative economic development outcomes, we add a control for latitude, from You and Khagram (2005) as also used previously in Treisman (2000). To control for simple wealth effects, we use the annual log of GDP per capita in constant U.S. dollars from the World Bank's Word Development Indicators (WDI) database.

\section{Models AND Results: Cross-Sections, FiXed EFfECTS, AND INSTRUMENTAL VARIABLE}

The econometric results are in three categories, culminating with fixed effects and instrumental variable models. We first present a set of annual cross-sections. The cross-sections show political instability to persistently correlate with financial market outcomes, even when controlling for the factors that have been prominent in the finance literature in the past two decades. While instability correlates persistently, several of the prominent other factors, such as legal origin, do not always correlate with financial outcomes.

\section{A. Time Consistency of Correlation in Year-by-Year Cross-sections}

To assess the potential relationship between political instability and financial development, we test first for time-consistency of instability, then move to country fixed effects tests, and then finally to instrumental variable regressions. As a first step, it is critical to test for the time-consistency of the variables that might explain financial development. Prior law and finance work has tended to work in the cross-section, with a large proportion of documented results taking place for cross-sections in the mid- to late-1990s. Rajan and Zingales (2003), however, show that it is imperative to test whether the variables of interest have a consistently positive or negative association with the dependent variable over time. Hence, we check for the consistency of political instability indicators for every year with available data in the past four decades. Political instability, the variable of interest, meets the first test, that of timeconsistency. 
We next test for endogeneity and unobserved heterogeneity as alternative explanations for the persistent association between political instability and financial development. To deal with the possibility of unobserved heterogeneity, one can use country fixed effects to partial out time-invariant factors. But for the early part of our sample time period political instability is highly time-invariant, making country fixed effects regressions invalid. However, starting in the late 1970s there is an increasing divergence in political instability both around the world and year-by-year. This increase in variation allows us to test for the impact of changes in political instability on financial development, nation-by-nation, via fixed country-effects regressions. The results, which are sharp, are presented below in Table 7. Lastly, to further deal with endogeneity concerns, we use a set of instrumental variables for political instability in Table 9, primarily based on considerations (and instruments) advanced in Alesina and Perotti (1996), Engerman and Sokoloff (2002), and Easterly (2007), and related to concepts brought forward in Acemoglu, Johnson, and Robinson (2001). Table 9, our last, shows political stability to robustly predict financial outcomes using these instruments.

We first estimate the following OLS, in Tables 3 and 4 :

(1) Financial outcome $=\beta_{0}+\beta_{1} *$ Political Instability $_{i}+\beta_{2} *$ French Civil Law origin $_{i}$

$+\beta_{3} *$ Common Law origin ${ }_{i}+\beta_{4} *$ Scandinavian Civil Law origin $_{i}$

$+\beta_{5} *$ Constructed trade share ${ }_{i}+\beta_{6} *$ Log of GDP per capita ${ }_{i}+\varepsilon_{i}$,

where the financial outcome in Table 3 is banking sector development for country $i$, and in Table 4 is stock market capitalization/GDP for country $i$ in Table 4 . The financial outcome is jointly determined by political instability, legal origin, constructed trade share, and the log of GDP per capita. In the unpublished Appendix, we estimate the same model, but with private credit/GDP, private bond market capitalization/GDP, and public bond market capitalization/GDP as alternative dependent variables. Results show political instability's strong association with all four debt measures.

In the last panel of Table 3 , we pool the 25 years of data and use a trend variable. The pooling yields 1656 observations and, using the same controls for origin, trade, and GDP per capita, has political 
instability significant at the .01 level. We also aggregate the repeated cross-sections in a panel analogue, by interacting the independent variables with time dummies. This result is presented in Appendix Table 3 .

Figure 2 abstracts the results thus far. We test whether political instability correlates closely with weak financial development, as seen in channel A. It does, and it does so independently of its tendency to weaken the economy overall (which it also seems to do), mapped out via channel B. It also does so independently of the legal origins channel - channel $\mathrm{C}$ - that has been proposed in the past decade. (Below we examine the strength of the channel running from instability to weak finance for reverse causation, via a country fixed effects model and an instrumental variables model in the later Tables 7,9 , and 10. We also check below for its robustness to economic growth. Instability does well in the fixed effects and instrumental variables models and is robust to indicators of economic growth.)

For stock market capitalization, the results are similar. Table 4 estimates specification (1), but with the financial outcome this time being stock market development for country $i$, jointly determined by political instability, legal origin, constructed trade share, and the log of GDP per capita. The results point to political instability having a negative and highly significant association with stock market capitalization divided by GDP, again while controlling for log GDP per capita, origins, and trade. As in Table 3, we present the Table 4 results for stock market capitalization year-by-year to examine the relationships for time consistency; the coefficient on instability was typically significantly negative. Lastly, we pool the results with a trend variable, as we did for Table 3's debt market specifications, with similarly significant outcomes for political instability.

The SPI index and its underlying source data end in 1982, rendering the index of limited value in examining the relationship between later political instability and financial development. Accordingly, we also use Banks' well-known index of political crises, which measures instability in later years. We construct a decaying index by using the current year's indication of instability, adding .99 of the prior year's measure, and then $.99^{2}$ of the prior year, and then $.99^{3}$ of the year before that, and so on, until the Banks data is exhausted; these results are reported in panel B of Table 4. Here too instability is typically significant. Decay rates of 5\% and 10\% produce similar results, as shown in the Appendix. 
The pooled results in the final panels of Tables 3 and 4 examine the instability-finance nexus with a much larger data-set than do the year-by-year cross-sections alone. But, since time consistency is important, we also present the year-by-year results in Tables 3 and 4, which is the higher hurdle to clear.

To further assess the correlation of political instability and financial development in nations having differing levels of wealth, beyond that handled with the wealth control, we also ran the key tests we report in Tables 3 and 4 by dividing the sample into OECD and non-OECD countries, to see if the effects were located primarily in the non-OECD countries. They were. (The results are reported in the Appendix.) Despite the lower number observations by dropping 30 OECD nations, the predictive power of political instability persisted and indeed the t-statistics on the correlations were often stronger in the less rich subsample than for the full sample. Variation in instability was weaker in predicting financial differences for the richer, OECD nations. But, since most OECD nations have been stable in recent years, that result suggests that a nation needs to pass a threshold of stability and deep-crisis-avoidance, that many developing nations do not pass it, and that once passed, other factors also play an important role in determining financial differences. ${ }^{8}$

Because one would expect political instability to negatively affect overall economic development generally and because weakly developing economies have a lower demand for finance, we wanted to assess better the extent to which the channel between political stability and financial development ran solely through economic growth. To do so, we re-ran our primary models controlling not just for log GDP/capita but also for economic growth. (These tables are reproduced at the end of the appendix.) The doubled economic controls ought to absorb much, or all, of any direct impact of instability on growth. What remains should be primarily a channel running between instability and financial outcomes. As before, political instability's significance persisted. In conjunction with the results for the non-OECD sub-

\footnotetext{
${ }^{8}$ Because OECD-member countries have been politically stable in recent decades and variation in political instability is highest among non-OECD member countries, political instability's effect on financial development is strongest in non-OECD member countries, as can be seen in the Appendix. Still, the strong political instability results were not driven by simple wealth differences: First, we control directly for log GDP per capita in all primary tables and find that political instability was still a highly robust determinant of financial development. Second, we show that the results for political instability are significantly robust to the use of instruments, as seen in Table 10. Lastly, while the instability effect in OECD nations was not as prevalent as it was in non-OECD nations, it was fundamental in earlier eras, such as the Great Depression, as Voth (2002) demonstrates, and
} 
sample described above, the evidence suggests a separate channel between stability and financial development.

We also examined the year-by-year cross-section correlations with controls for political systems, judicial characteristics, corporate law quality, and latitude. We discuss these robustness checks below, but note here that in all cases political instability persisted as generally significantly correlated in the year-byyear cross-sections. We report these robustness checks in the appendix.

The cross-sectional conclusion: political stability strongly correlates with financial development in a time consistent manner and those correlations are robust to alternative explanations.

\section{B. Fixed effects and changes in instability in the 1990s}

Omitted variable bias needs to be confronted. Financial development has been a topic of intense scrutiny in the past two decades, with multiple explanations having been brought forth to explain financial depth and breadth. As such, we see the omitted variable risk here as real, as always, but it's less sharp here than for a fully new inquiry, because we have been able to control in the cross-sections for every prominent explanations of recent decades - legal origin, trade openness, basic geography of latitude, and corporate law quality. Omitted variables may still bias the results, but the omitted variables are not those that have been brought forward in the past decades of work on finance.

Nevertheless, to better assess the possibility of omitted variable bias, we further probe the relationship between political instability and financial outcomes, first via regressing changes in stock market development on changes in instability in the 1990s, then via a fixed effects model first, and then via an instrumental variable model. In each instance, political instability predicts financial outcomes.

1. Changes in instability over time. In Table 5, we examine the relationship between changes in political instability and changes in stock market capitalization, by estimating the following OLS regression:

(2) Change in 1990s-era Stock Market Development ${ }_{i}=\beta_{0}+\beta_{1} *$ Change in Political Instability $_{i}+$

the $19^{\text {th }}$ century, as Brown (2006) demonstrates, when instability varied more sharply in the wealthy West than it has in recent decades. 


$$
\begin{aligned}
& \beta_{2} * \text { Log of GDP per capita in } 1990_{i}+\beta_{3} * \text { Constructed trade share } \\
& i \\
& \beta_{4} * \text { Latitude }_{i}+\beta_{5} * \text { Increase in } 1990 \text { s-era Economic Development } \\
& i
\end{aligned}
$$

where the change in 1990s-era stock market development for country $i$ is jointly determined by the change in political instability, the log of GDP per capita in 1990, constructed trade share, latitude, the increase in 1990-era economic development in that country, and the level of initial political instability in 1990. Changes in political instability predict changes in stock market capitalization, with controls in place for economic growth, trade, and initial starting economic condition. The effect is most pronounced in nations that started with high political instability, again suggestive of a threshold effect, with the small variation in the developed OECD nations being determinative.

2. Fixed effects. To reduce the possibility of omitted variable bias, we sought to estimate the following panel regression with country fixed effects and year dummies:

(3) Stock Market Development ${ }_{i t}=\beta_{0}+\beta_{1} *$ Political Instability $_{i t}+\beta_{2} *$ Log of GDP per capita ${ }_{i t}$ $+\delta_{i}+\gamma_{t}+\varepsilon_{i t}$,

where stock market development for country $i$ in year $t$ is jointly determined by political instability, the $\log$ of GDP per capita, country fixed effects $\delta_{i}$, and a set of year dummies $\gamma_{t}$.

For the fixed effects model, the SPI index was unavailable, because it is an invariant measure of political instability for the 1960-1982 period. However, the Banks instability variable is a year-by-year measure, which allows for a fixed effects model.

In Table 6, we use the decay index we constructed from the Banks raw data to predict stock market capitalization, using the WDI and Beck et al. measures of stock market capitalization. The available data in each covers in excess of 80 countries, with approximately 1000 observations. The results show instability to negatively and significantly predict stock market capitalization, with a p-value of less than .01 and R-squared values .19 and .32 . 


\section{Instrumental Variables}

Could financial development primarily determine basic political stability? We suspect that there is here, as is often the case, simultaneity and bidirectionality. We are also confident that once a nation is generally politically stable, further financial development can further increase economic opportunity, raise the standard of living of the least well-off, and thereby induce a virtuous cycle (consider Beck, Demirgüç, and Levine (2007)). Recent images of massive demonstrations in Greece following financial disruptions there illustrate that disruptions in national finance can disrupt political stability. But we want to check whether the principal route to basic political stability lies through financial development. Did weak financial development in, say, the 19th century primarily determine 20th century instability (as opposed to just being a supporting factor)? And then did that financially-induced instability in turn become the primary channel weakening $20^{\text {th }}$ century financial development?

Neither a two-stage regression nor modern law and finance theory favor the primary channel as being one that runs from weak finance to high instability, particularly the severe instability that is the basis for our primary investigation.

First, the two-stage regression: The fundamental geography of settlement led some nations to turn to crops that were best developed with landholdings worked by large pools of unskilled labor. That setting produced deep inequality, both initially and over time, from which institutions that perpetuated inequality emerged, a process prominent in Engerman and Sokoloff's (2002) work, which we follow in this dimension. Acemoglu, Johnson, and Robinson's (2001) work on how relative settler mortality in the colonies induced institutional choices that persisted to this day and the related modeling in Acemoglu and Robinson (2006) are also relevant. It is not easy to see how financial backwardness would induce underlying instability-generating geographic conditions here. Moreover, the economic and political science literature, to the extent it does not attribute instability primarily to inequality, attributes it to ethnic fractionalization, as seen in Alesina and Spolaore (1997). Financial backwardness is unlikely to induce ethnic fractionalization, although it is plausible that fractionalization induced weak financial development both directly and by increasing instability. Because unequal societies tend to be ethnically heterogeneous, 
as Glaeser (2006) reports, and distributional fights in unequal societies impede economic growth, as Alesina and Rodrik (1994) indicate, well-established channels run to instability that do not run from financial development. Overall it seems unlikely that early financial backwardness primarily caused $20^{\text {th }}$ century political instability. But, again, our data does not fully rule out that possibility. ${ }^{9}$

The best way to think of the likely bidirectionality here is as follows: Political stability, based on enough inequality-reducing (or the absence of strong inequality-maintaining) institutions, is foundational for sparking financial development. This channel is represented by arrows E and A in Figure 6 and illustrates the core concepts of the Engerman and Sokoloff $(2002,2005)$ literature. Once the threshold of basic stability is achieved and development starts, further financial development could strengthen the economy and sometimes even reduce inequality, as illustrated by arrows D2 and B in Figure 6.

We first instrument the SPI index with historical and largely exogenous variables used in adjacent inquiries, focusing on crops, inequality, and fractionalization. We set up the instruments with the following OLS regression:

(4) Political Instability ${ }_{i}=\beta_{0}+\beta_{1} *$ Size of the Middle Class $_{i}+\beta_{2} *$ Ethnic Fractionalization $_{i}$

$+\beta_{3} *$ Frankema Land Inequality Measure ${ }_{i}$

$+\beta_{4} *$ Rice Export/Total Agricultural Exports in $1975_{i}$

$+\beta_{5} *$ Sugar Export/Total Agricultural Exports in $1975_{i}$

$+\beta_{6} *$ Cocoa Bean Plus Cocoa Powder Export/Total Agricultural Exports in $1975_{i}+\beta_{7} *$ Coffee Export/Total Agricultural Exports in $1975_{i}$ $+\beta_{8} *$ Tobacco Export/Total Agricultural Exports in $1975_{i}+\beta_{9} *$ Mean Temperature Above 32 degrees Celsius ${ }_{i}+\varepsilon_{i}$,

where political instability for country $i$ is jointly determined by the size of the middle class, ethnic fractionalization, a set of variables measuring the country's reliance on specific crops (variables that are the focus of Engerman and Sokoloff's (2002) theory about inequality-perpetuating conditions), and extreme environmental temperature in that country.

\footnotetext{
${ }^{9}$ The earliest years covered by the World Handbook were used, showing statistical support for the fact that political disorder in years dating back to 1948 predicted weakness in subsequent debt market development in 1965.
} 
The task faced two categories of challenges, with the first conceptual. Instability can degrade economic activity directly. This degradation could in turn lower the demand for finance. But in addition to showing political instability's general robust impact, through any and all channels, we also want to assess the plausibility of a channel running from instability directly to the supply of finance. Our instrumental variable strategy was to use variables inspired to Engerman and Sokoloff (2002) and Easterly (2007) - crops and natural phenomena (with the feel of the weather instruments first used in such two-stage analysis), natural phenomena that tend to induce (or reduce) inequality, but that should have a limited direct impact on financial outcomes. But that strategy does not in itself exclude the possibility that instability degrades economic activity directly, with directly impacting finance, and that it is only the resulting economic degradation that reduces the demand for finance. To reduce the likelihood that the instrumental variable model is primarily picking up this channel, we control for overall economic outcomes in two ways. First, the standard GPP/capita is in every model. Second, we add a second control for ongoing economic growth. By using these two controls, we reduce the likelihood that the model is just running from inequality-induced instability to economic degradation, as the controls should pull that channel out from the results. Because the two-stage model yields significant results for political instability even with the doubled-up economic controls, it supports the likelihood of an instability-to-financialsupply channel.

The second challenge was that the project faced multiple data constraints. Many factors behind instability have not been measured across many nations and years, reducing the number of observations available. Still, as the estimation in model 1 of Table 9 shows, the size of the middle class in 1960 alone explains much variation in the SPI index. In the full first-stage, we expand upon the simple middle-class model, adding national geographic propensity to rely on crops best grown via large pools of unskilled labor - a traditional explanation in adjacent academic work for inequality and instability. While there is a risk of some secondary reverse causation reducing the power of crop-propensity instruments financial weakness may compel production of some crops that need no financing — the agricultural evidence strongly points to the instruments' basic validity here. Easterly (2007) shows their validity: 
[C]rop endowments measure ... the percent of national arable land area suitable for different crops, taking into account such factors as soil, rainfall, temperature, and elevation. [Source omitted] discusses the botanical mechanisms by which different ecological zones are compatible with some types of crops and not with others. For example, sugarcane does not grow below 15$16^{\circ} \mathrm{C}$, needs an average of about $1200-1500 \mathrm{~mm}$ rainfall a year, and favors level rather than steeply elevated lands [source omitted]. In contrast, wheat photosynthesizes at low temperatures $\left(15\right.$ to $\left.20^{\circ} \mathrm{C}\right)$ and cannot be grown in the warm tropics (FAO, 2005). These characteristics have thus plausibly remained constant over time, thus reflecting historical conditions for inequality.

Rajan and Zingales' (2003b: 152) anticipate Easterly's analysis: “Some lands lend themselves to intensive farming, while others lend themselves to a mode of agriculture such as plantations that is more extensive. This may partly explain why Costa Rica has had a more democratic history than Colombia." Bobonis (2008) confirmed this view when examining contrasting cultivation qualities earlier in Puerto Rico. Where land and weather supported labor-intensive cultivation of crops such as coffee, more intensive coercion institutions emerged, such as more rural police and well-funded paramilitary forces. Inequality persisted because of institutional structure and the elite's interest in having a pool of unskilled labor: public schooling was less prevalent in such areas and both adult and child literacy was persistently lower than in other areas of the island.

The land inequality variable we use is Frankema's (2006). ${ }^{10}$ Highly unstable countries tend to have very high average temperatures, with instability presumably due to the kind of landholdings and resultant inequality that the geography induces. In principal, inequality could affect financial development other than through political instability and that leakage, if substantial, could defeat its usefulness as an instrument here. Two further tests indicate though that this side channel does not dominate. First, we reinserted the inequality variable in the second stage; the coefficient was not significant. (The Appendix displays this model's results.) Second, changes in inequality did not directly predict stock market development when we ran the model without political instability, suggesting it is not primarily a direct determinant of financial development but is part of the bundle of determinants of democratic political instability, with that instability then having a detrimental effect on financial development. While further work here is appropriate and the instrumental variable model is not immune to weakness, including the

\footnotetext{
${ }^{10}$ Frankema's measure is constructed such that higher values signify more land equality.
} 
number of surviving observations and the potential for an instrument to itself have some endogenous qualities, these two results suggest that a plausible initial interpretation of the instrumental variable model is that the channel running from inequality and financial development largely goes through political instability. $^{11}$

In Table 10, we instrument the SPI index from the column 6 results of Table 9 to predict financial development. We estimate the following IV model:

(5) Financial Market Development (using alternative DVs in succession) ${ }_{i}=\beta_{0}$

$$
\begin{aligned}
& +\beta_{1} * \text { Instrumented Political Instability using Equation (4) above }_{i} \\
& +\beta_{2} * \text { French Civil Law origin }{ }_{i}+\beta_{3} * \text { Common Law origin }_{i} \\
& +\beta_{4} * \text { Scandinavian Civil Law origin } \\
& i \\
& +\beta_{5} * \text { Constructed trade share } \\
& +
\end{aligned}
$$

where financial market development for country $i$ is jointly determined by the instrumented political instability using Equation (4) above, by legal origin, by constructed trade share, and by the log of GDP per capita.

The instrumented instability index, using the instruments from model (6) in Table 10, significantly explains averaged bank loans to GDP for the years 1965-1975. It also significantly predicts bank loans to GDP for the years for which the SPI index overlaps with available financial development data. (It is robust in a non-OECD subsample.) It significantly explains the earliest available year of stock market development data from the World Bank (for 1988, which is six years after the end of the 1960-1982 period the SPI index covers). As we report in Table 10, Beck Demirgüç-Kunt, and Levine's (2000) financial data, which starts several years earlier the World Bank's, yield similar results for the importance of political stability. Although not robust for every year, the evidence using instrumented SPI is

${ }^{11}$ Some of that future work could account for Beck et al's (2007) finding that increases in financial development were associated with subsequent reductions in inequality. However, they did their work with the old version of the Gini panel, which, although the best available to them at the time, was seen as having serious embedded problems. With the recent updates, this association no longer obtains, particularly when run in country fixed effect models. (We would expect, though, that redistribution programs that support the poor through enhanced credit access for them would show an association between these types of financial changes and inequality reductions; our impression is that these programs are not yet widespread enough to have worldwide effects.)

We reexamined our results, using the recently updated, but not fully vetted GINI data. As with the currently and widely used GINI database, changes in inequality did not directly predict stock market development, as can be seen in the appendix. 
sufficiently consistent across time periods and development indicators to indicate that one should not reject, and indeed that there's supportive evidence of, causality as running from stability to finance. Similarly, we ran this instrumental variable model with private debt (and reproduce results in the appendix). While less robust, it also yields significant results in a number of years in the 1965-1982 period for which we have data.

Each model in Table 10 is consistent with the preferred test of overidentifying restrictions. We used the "estat overid" command in STATA after running two-stage least squares models through Panels $A$ and $B$ of Table 10. In the first model of Panel A, the resulting chi-square is $10.23(p=0.25)$. In the second model A, the chi-square is $5.71(\mathrm{p}=0.68)$. In the third, the chi-square is $7.35(\mathrm{p}=0.50)$. In the fourth, the chi-square is $4.02(\mathrm{p}=0.86)$. In the fifth, the chi-square is $7.50(\mathrm{p}=0.48)$. In the sixth, the chisquare is $5.99(p=0.65)$. In the first model of Panel $B$, the chi-square is $8.60(p=0.38)$. In the second, it is $6.38(\mathrm{p}=0.60)$. Hence, the null assumption of valid instruments cannot be rejected by this test. Using the "estat firststage" command in STATA, we find that the instruments are particularly strong for explaining the stock market development results in Model 5 of Panel A (F-statistic=17.70; $=0.00)$; Model 6 of Panel A (F-statistic of 16.67; $\mathrm{p}=0.00$ ); and Model 1 of Panel B (F-statistic of 105.40; $\mathrm{p}=0.00$ ); and the debt market development results in Model 2 of Panel B (130.86; $\mathrm{p}=0.00)$. The first-stage F-statistics for Models 1-4 of Panel A are somewhat weaker: the $R^{2}$ in the first stage for those models is relatively high (greater than 0.46 ), but the $F$ statistics do not surpass the usual rule of thumb of 10. Finally, the results of the post-estimation "estat endogenous" tests in STATA for every model of Table 10 suggest that political instability can be treated as largely exogenous under the usual analysis of instrumental variables. Only in Models 5 and 6 of Panel A are the p-values for the robust score chi-square below 0.10; in those two models the p-values are above 0.05 . In all other models the p-values are between 0.26 and 0.91 .

Regardless of the strength of instrumental variable analysis, in general or as applied here, an important conceptual basis exists for strong reverse causation being unlikely here. A main thrust of the last decade's law and finance inquiries is that government and legal institutions of some sort are central to protecting investors from wrongdoers. But a nation with an unstable political environment could not 
easily produce good government and strong investor protection institutions while remaining unstable (Svensson (1998: 1318-1319)), with that investor protection then inducing financial development (in the midst of pervasive political instability), and with that good financial development then later stabilizing that nation's previously-unstable polity. The government institutions that investors need for protection are inconsistent with an unstable, unreliable polity. Hence, a significant direction of causation - to fit with main findings of the prior decade's law and finance inquiry — must run from stability to finance.

The instrumental variable results do not mean that other channels do not exist, nor are the instruments themselves immune to any challenge. Surely there is some leakage from the channel, with severe inequality inducing some financial backwardness other than through political instability. But, again, the robustness of instability to measures of economic growth (as shown in the Appendix), the fact that inequality, when inserted in the second stage is not significant and does not significantly correlate with financial outcomes when run without political instability, and the weakness of the association between changes in inequality and changes in financial development, each indicate that that the leakage does not overwhelm the channel we examine here. The instruments derive from and revolve around the possibility that historical inequality and inequality-inducing exogenous institutions affect political instability, which in turn affects financial development. Although the channel has not been closely examined with recent financial data, it is derived from to concepts in play as early as the time of the Greek philosophers and, more recently, in work by Acemoglu, Johnson, and Robinson (2001), Alesina and Perotti (1996), Engerman and Sokoloff (2003), and Gradstein (2007).

Still, we acknowledge the difficulty of finding perfect instruments, because it is exceedingly difficult to rule out any reverse causation and any possibility that the instrument affects the outcome other than through the variable of interest. Yet the existence of an important channel running from severe economic inequality to political instability to financial backwardness is not just consistent with the instrumental analysis, but also with prior theorizing from political science and development economics and such a channel is a good fit with the year-by-year cross-sections with multiple measures of political instability going back four decades that we present. A strong and robust association exists between 
political instability and financial development and the instrumental variable analysis, even if it does not resolve the issue, points toward a plausible causal channel running from the former to the latter.

\section{DisCUSSION AND FURTHER ROBUSTNESS CHECKS}

\section{A. Sources of Instability: Does Stability Derive from Legal Origin?}

In this section, we first consider the possibility that prominent explanations for financial differences affect financial markets by inducing political stability. If political instability is rooted in important part in the persistence of a property-owning middle-class as Alesina and Perotti's (1996) and our results, among several, suggest, and if it independently affects financial markets, then (1) current research agendas need to broaden and (2) policy advice based on some prominent explanations, such as to primarily emulate investor protection institutions of developed countries, is incomplete. For some nations it might even be incorrect. Investor protection programs may be insufficient, or might be undone by an unstable polity.

Even if the currently prominent explanations largely determined political instability, political stability would play a key role in law and finance. First, we would thus have identified an important channel to financial development. Second, adjacent literatures have focused on conduits to instability due to income and wealth inequality, and ethnic fractionalization. Thus, even if prominent explanations for financial backwardness flowed through instability, other conflicts and institutions might further destabilize nations that would otherwise be stable.

A first hurdle here is to see whether instability just proxies for legal origin. In assessing whether it does, one can consider several national pairings that illustrate the results in the more rigorous examination below. Nigeria - a common law country — experienced instability exceeding that of nearby Ivory Coast - a civil law country - suggesting that local conditions and not origins have much to do with instability. (Nigeria had five years of political instability during 1960-2003, according to Banks' (2005) widely-used measure of instability, the Ivory Coast two.) As measured by the number of military coups since independence, common law Nigeria is the most unstable African nation, Amadife (1999: 620) narrates. 
For many of our regressions, legal origin either fails to predict financial development or is not consistently robust in doing so, but political stability predicts financial development regularly and is more often robust to other influences. To exemplify, Liberia's, Nigeria's, and the Sudan's common law origin did not give those nations — subject to violent conflict and political instability — significant advantages over civil law nations such as the Ivory Coast, Senegal, and Togo in achieving stability. During the two decades after African independence, legal origin did not predict the sixty post-independence African coups that Rake (1984: 25) compiled. Legal origin did not enable Zimbabwe to overcome the racial and economic conflict that destabilized the polity, damaged property rights, and led to sharp economic and financial decline. Richardson (2005).

We also looked for prior evidence that legal origin caused or prevented political instability or its constituent elements and did not find any. Economic historians focusing on political instability have not reported legal origin as a key channel to instability or related outcomes. For examples, see Dye (2006) and Sanders (1981), who review the literature on political instability, indicating many inputs to instability, including ethno-linguistic fractionalization, a weak middle class, and inequality, but do not mention legal origin. Indeed, that literature emphasizes that civil law countries are too statist, with a heavy government presence, and fail to allow financial markets to develop well. The instability channel in play here is largely the opposite: a lack of state capacity, not an excess. Huntington (1968) has made a similar point.

Still, political instability moderately correlates with French civil law. Although the annual political instability decay index never has a greater than 0.30 correlation with French Civil Law across the years (and typically correlates in the 0.08 to 0.20 range), the SPI Index has a 0.45 correlation with French Civil Law. (SPI's and the annual indices' correlation with all other variables is noticeably smaller.)

To test formally for a collinearity problem, we examined the models with and without the legal origin variables and with and without the political instability variables. Our doing so revealed no significant change in either set of coefficient results. Normally that would end the matter, even with higher collinearity. Moreover, the decay and country fixed effect models suggest a persisting effect of prior instability in disrupting later finance, a result more consistent with a varying cause than with the 
rigid effect of origin. We also found substantial variation of political instability inside each origin common law nations such as Liberia, Nigeria, and the Sudan have been quite unstable, a variation that also suggested no serious collinearity problem. We tested whether the coefficients on the political instability variable were significantly inflated by legal origin. They were not. The variance inflation factor for political instability was consistently less than 1.70 throughout and conventionally concerns about multicollinearity arise only if the factor approaches 10. Similarly, examining the variance inflations factors showed that the coefficients on the legal origin and other variables were not meaningfully influenced by collinearity. The mean VIFs across varying specifications are consistently less than 3.25.

We also examined whether standard thinking in adjacent disciplines — that instability often results from inequality and ethnic fractionalization — was in play in our data. Income inequality, as proxied by the size of the middle class, was indeed highly robust in explaining political instability. Moreover, the occasional correlation between French legal origin and political instability typically disappears when we control for usual explanations for instability such as a nation's dependence on crops using unskilled labor, its land inequality, and its ethnic fractionalization, as Table 10 shows. Lastly here, legal origin differences have not consistently predicted financial development over time in recent decades, other than in the 1990s, as Roe and Siegel (2009) show. Instability does so more consistently.

Additionally, the country fixed effects panels in Table 7 shows the in-country variation of instability strongly predicting financial outcomes, with $p<.001$. Since these fixed effects regressions take out unobserved as well as observed country-specific characteristics that are stable over time — like legal origin — they point to political instability being strongly associated with financial underdevelopment quite apart from both legal origin and unobserved heterogeneity concerns. ${ }^{12}$

${ }^{12}$ We subjected the Table 7 specification to further robustness checks. We interacted instability with GDP per capita, with the result indicating that much of the instability impact is in the developing nations, with the more political stable ones developing better financial markets. Results are in Appendix Table 7A. We also ran the Table 7 specification with a trend variable instead of year fixed effects; results were again similar. We also ran the same specification, with both the trend variable and the instability*GDP/capita interaction, with similar results. Appendix, Table 7B. 


\section{B. And What Causes Political Instability?}

We do not aim to independently contribute to the literature on the causes of political instability, but we do want to discuss it. Alesina and Perotti's (1996) find that severe economic inequality is the primary determinant of political instability and we confirm this finding in our data as well. Investor protection institutions may not work well in highly unequal, unstable political environments.

Other factors contribute to instability, such as ethnic and religious strife, see Alesina and Spolaore (1997), Angeles (2007), Collier (2000: 9, 11-13), and Easterly and Levine (1997: 1223); cf. Ayyagari, Demirgüç-Kunt, and Maksimovic (2006). Unequal societies also tend to be ethnically heterogeneous, Glaeser (2006) reports, and resulting distributional fights impede economic growth, Alesina and Rodrik (1994) and Persson and Tabellini (1994) indicate.

\section{The Time Invariant SPI Index}

As we have noted, the SPI index measures overall instability for 1960-1982. Many financial outcomes we report are for the subsequent quarter-century. But where we have outcome data going back before 1982, we use the SPI index to look at those earlier outcomes. We do so for two reasons. One, the underlying year-by-year instability measures were highly time-invariant in the first several decades after World War II. As a robustness check, we confirm and report in the Appendix that political instability from years 1948-1964 (using the primary source data used for Alesina-Perotti's political instability index) significantly explains financial development in 1965, when their financial data begins. Secondly, as the outcome years approach 1982 , the issue becomes trivial. ${ }^{13}$

Does variation in political instability after 1982 (when the SPI index ends) continue to predict financial market development? To find out, we use additional measures of political instability: the moving index of government crises from Banks (2005) and the IMD instability surveys (over 1999-2004). Although government crises as measured by Banks (2005) were approximately one-third to one-half as

\footnotetext{
${ }^{13}$ After we present our primary results and robustness tests, we present a two-stage instrumental variables model in Tables 9 and 10 that indicates that reverse causality is not a significant concern.
} 
frequent in the 1990s as they were in the 1960s and 1970s, the moving index has explanatory power even during the 1990 s and early 2000 s. $^{14}$

After the secular decline in political instability in the 1980s, neither the 1960-1982 SPI nor Banks' Cross-National index predicts debt market development, but variation in lower-grade instability predicts equity market development, as Table 4's year-by-year cross-sections show. Perhaps debt markets, for reasons requiring future research, are less affected by ongoing low-grade political instability than they were by the earlier high instability in some nations. ${ }^{15}$ Also, because equity investments have a longer horizon than debt investments, investors expecting short-term stability while being very uncertain about long-term prospects for stability may be more willing to invest in debt and less willing to invest in equity.

Banks' Cross-National instability measure is also negatively and often statistically significantly related to stock market capitalization. (These results are also robust to using an alternative stock market measure: external market capitalization/GDP for 1996-2000, which is the dependent variable La Porta et al. (2006) study. We report this result in Table 8.)

Our other measure of recent political instability also predicts the strength of the primary financial outcomes. Annually since 1999, the IMD Survey has had several thousand senior business executives around the world rate nations' political instability. We averaged their reported perceptions. The averages predict stock market capitalization, bank credit, and private credit quite strongly and do so with the standard controls in place, as shown in the Appendix. We run similar tests on the World Economic Forum's similar 1997-2000 perception measure. It also robustly and consistently predicts financial outcomes. The results are consistent and robust both when we use the survey measure directly and when instrumented, as the Appendix reports.

Each measure of political instability significantly predicts weakness in financial development and is quite robust to explanations for financial development that have become prominent in the past decade.

\footnotetext{
${ }^{14}$ The source data for Alesina-Perotti (1996) index was not collected after 1982, barring us from extending the AlesinaPerotti measure. But Banks' Cross-National Time Series database (the basis for Barro-Lee's well regarded and much-used measures of political disorder) goes up through 2003.
} 
Do SPI's components separately predict financial outcomes? The index has two major components, one of the severity of political crises (measured by coups, attempted coups, assassinations, and domestic political violence) and one based on the regularity of a nation's democracy. We decompose the index (in Appendix Table 3d) but find no persistent privileging of crises over democracy or vice versa. Both seem important. The regularity of elections is important, but alone does not dominate the results. Possibly a stable democratic polity with a broad middle class insists on property protection (including outside investor protection), with stability giving the government the means to provide it.

This last result is relevant to seeing how nations that are stable in an intuitive sense fit here Pinochet's Chile or the pre-1989 Soviet Union, for example. Although governments in each persisted in power, neither would have been stable as measured, as both relied on violence to maintain their continuity and neither were democratic. Although stable in an intuitive sense, neither would be high on the political instability measure (or, perhaps, as we might label the characteristic were we writing on a clean slate here, a measure of democratic political regularity) here. ${ }^{16}$

\section{Further Robustness Checks}

As we noted previously, we subjected the cross-sectional correlations to a battery of robustness checks, including latitude, presidentialist political systems, judicial branch characteristics, and corporate law quality, each of which have been advanced as important to financial development. These are reported in the appendix and briefly discussed next. They do not change the basic results: instability persists as regularly and significantly correlated with financial market depth and breadth.

Judicial characteristics could play one of two roles. They are seen as key channels to property rights, of which investor protection is a subset, and financial development. Hence, property-degrading political instability could be an aggregation of weak institutional channels of property rights protection.

15 The IMD measure of recent managerial perceptions predicts differences in debt outcomes, perhaps because a perceptions survey picks up finely-grained differences when the aggregate level of violence and instability declined in many nations in the 1990s. Equity markets may require stronger institutional support than debt markets.

${ }^{16}$ The logic here is that instability undermines a nation's capacity to protect investors and develop finance, but this is not the only channel to financial atrophy. A stable polity may be capable of protecting investors but decide not to, due to its internal political dynamics with anti-finance parties controlling the polity. Rajan \& Zingales (2003) and Roe (2000) examine such possibilities. 
Second, at least in theory, judicial review could confine the destabilizing tendencies of a grasping legislature or executive.

Prior political science analysis would make one skeptical that either judicial channel would strongly affect political stability, as that analysis had judicial review and judicial independence as more likely to reflect underlying political consensus (and stability) than to cause it. Whittington (2005: 583, 594), a political scientist, states: "For ... frequent [judicial] constitutional invalidation of legislation and executive action to be sustained over time, the courts must operate in a favorable political environment." And, "[p]olitical scientists have been skeptical of the significance of truly counter-majoritarian judicial review, which would seem unlikely to find political support in a democratic political system.”

As for judicial independence, legal scholars view the judicial branch as less powerful than the legislative and executive branches. Bickel (1962: 1) begins his legal classic by stating that, despite being "the most extraordinarily powerful court of law the world has ever known," the American Supreme Court is the "least dangerous branch of the American government" (emphasis added). Its apparent independence derives from the polity's strong consensus on norms and institutions such that first-order political institutions accept review from a second-order one. Judicial independence reflects, but does not cause, the stability of the other branches. Despite this cause for skepticism, we ran the tests. As reported in the Appendix, instability is robust to judicial variables. The latter are generally not robust to instability.

The judicial and presidential results point to a channel running from instability and its causes to financial backwardness, a channel that does not simply reflect the institutions typically seen to help stabilize a polity. There seems to be a factor — political instability, presumably due to severe economic inequality — that degrades financial systems (or prevents them from developing) and that is independent of the standard measures of the quality of political institutions.

\section{E. Interactions with Other Existing Theories}

The data suggests political stability propels financial development and instability retards it, independently of instability's effects on the economy overall. As we indicated above, we re-ran our main 
regressions by adding the WDI's annual growth rate for each nation; the political instability measures' significance persists, providing strong evidence that there is a direct channel from political instability to weak financial development, one that does not simply go through economic growth. (Results are reported in the Appendix.) This key channel to financial backwardness runs independently of origins-based investor protection, trade openness, and related explanations. But this result obviously does not mean that the other theories lack relevance. Trade openness is typically significant too. The colonial endowments explanation may work its way through political instability to financial markets, because extractive settlement strategies bred colonial inequality and supporting institutions, with that inequality and those institutions continuing up through the modern era. But even so, it remains plausible that it is modern instability, and not just poor endowments directly, that mainly impedes later financial markets. In any case, as the Appendix shows, the political stability results are robust to colonial endowments. The investor protection arm of modern law and finance persists, but it may depend as much on relative political stability as on previously-advanced considerations.

How political instability interacts with the strength of stabilizing institutions remains to be sorted out and, while important, is secondary to first seeing that relative political instability needs to be put into the causal chain. First, a nation's current instability could result from its current political institutions being unable to stabilize the polity, while a nation with stronger institutions could contain that instability. Second, weakened stabilizing institutions could interact with strong political instability to undermine finance, either directly or by degrading investor protection institutions. Figure 3 illustrates these channels to financial backwardness. Moreover, the current weakness of a polity's stabilizing institutions could be due to severe historical inequality having prevented politically stable institutions, in a way similar to how Engerman, Haber, and Sokoloff (2000) show that poor institutions developed in New World economies that were based on exploitive, plantation-style labor. (This could be illustrated by adding an input to the left of the (contemporary) Political Instability/Weak Stabilizing Institutions box in Figure 3, one for historically destabilizing institutions.) Also, current instability could be so severe that what would 
otherwise be satisfactory stabilizing institutions cannot contain the explosive instability. ${ }^{17}$ Glaeser, Scheinkman and Shleifer (2003) model how severe inequality can degrade institutions, either because the wealthy degrade them for their own benefit to reduce the have-not's access to better institutions or because the have-nots, seeking to redistribute to themselves, degrade property institutions that protect the wealthy. Claessens and Perotti (2007) review similar channels. Rajan and Zingales (2003a) and Roe $(1998,2003)$ in particular indicate that the strength of property rights is partly a function of how it is distributed: Our results here, with inequality-dependent instability damaging financial development, support these analyses. The degree to which each of these channels is in play is well worth exploring. The key point though is that the evidence here points to relative political stability as a major factor in the causal chain that explains financial development and financial backwardness.

\section{FUTURE WORK: SPECIFYING THE CHANNELS}

We aim to broaden the research agenda for financial development by furthering the existing inquiry into its political economy bases. What else needs to be done here?

\section{A. Specifying the Channels}

We have noted several plausible channels from instability to financial backwardness already. Here we discuss them further. Future work would be needed to understand which channels are the most important conduits running from political instability to financial backwardness.

As we noted above, instability and civil wars have been frequent in the developing world during the past half-century. Not only have such armed conflicts not been rare (Banks (2005)), they have not been short, with many lasting for more than a decade, and they have not been cheap, costing many affected nations more than $50 \%$ of their pre-conflict GDP, as Fitzgerald (1987), Richardson and Samarasinghe (1991), and Lindgren (2005: 10-12) show. Such conflicts have been numerous in the past half-century, but less frequent recently.

\footnotetext{
${ }^{17}$ We do not seek here to uncover how institutions and instability interact. Our aim is to show that instability significantly affects financial development and does so independently of the channels that run from or through legal, investor protection, and
} 
In highly unstable polities, public officials do not develop private financial markets because they have more basic tasks to handle. Instability often renders social capital investments, such as entrepreneurs' building reputations for reliability, less valuable (Collier (1999: 169-170)). Entrepreneurs see little point in investing in their reputational and social capital if they expect to be unable to draw on it. Instability makes formal rules more unstable (Maurer (2002)), legal reform projects fail (Dye (2006: 190)), weakens the institutions for good macro-economic policy, and enforcement tools for protecting property deteriorate (id.: 195). Civil wars undermine the state, as Collier (1999: 168-169) says, as they weaken "both its institutions such as property rights, and its organizations such as the police. ... [T]he rule of law diminish[es]. The enforcement costs of contracts consequently rise and the security of property rights is reduced." Governments cannot credibly commit to broad, long-term property rights protections in the midst of political instability, as Haber, Razo, and Maurer (2003: 19) explain was the case for Mexico:

[G]overnments under siege, or factions aspiring to be governments, cannot afford to tie their hands. This produces two problems for asset holders. First, they cannot know with any degree of certainty the content of government policies in the future. Second, asset holders know that the government has strong predatory incentives concerning property rights - regardless of its stated ideology. If the [current] government is not predatory, someone else [may well] be ... .

A politically stable nation provides stronger foundations for financial development. Marketplace reputations and informal mechanisms are made worth developing. Cf. Allen, Qian, and Qian (2005); Franks, Mayer, and Rossi (2008); Mayer (2008). Governments can turn to building the institutions of financial development when basic issues of order have been resolved. Capital flight decreases. Entrepreneurs can focus their efforts on developing their businesses instead of mitigating the impact of local political instability. As their businesses grow, the entrepreneurs demand for financing increases.

\section{B. Refining the Understanding of Instability's Impact}

Future work should refine how we understand instability's impact: Instability via a sharp governmental change that led not to persistent turmoil but to a stable resolution and then stronger, not

overall economic development. Current instability and severe inequality, whatever are their underlying causes, could either stymie stabilizing institutions from emerging or stymie otherwise acceptable ones from functioning well. 
weaker, financial development over the long-run. On the other hand, equality-enhancing movements that fail may yield years of instability as citizens fight over resources, income, and property.

Because the most prominent political instability index primarily measures violence, a strong authoritarian regime might have modest financial development — because the players expect an eventual end to the regime that will upset prevailing arrangements — yet be coded as stable, if ongoing violence is low but fears of disruption are high. Refinement is in order if rigidity breeds expectations of future political instability. Dutt and Mitra (2008) uncover a parallel channel running from inequality to instability to policy difficulties. Their results are encouraging for this inequality-to-instability-to-outcome channel. (Instability via failed coups, in contrast to successful ones, had little impact on their outcome variables, while for our dependent variables of financial development, instability via failed coups is quite germane.)

Lastly, equality, perhaps in particular via a broad property-owning middle-class, may keep a polity stable once that equality is achieved, but it may not be easy to generate that equality in societies that do not already have it. Some reforms have succeeded - post-War land reforms in Taiwan and South Korea come to mind - others failed or began periods of extended political instability. The basic dilemma is not new: Aristotle sketched out these considerations several millennia ago in The Politics: although "the equalization of property ... tend[s] to prevent the citizens from quarreling (Aristotle (1986: 45, Bk II, Sec. VII), efforts to create that equality induce the very conflict that the polity needs to avoid (id: 142-144, Bk $\mathrm{V}$, ch. 1.). To avoid turmoil, it is better "to live where equality prevails" (id: $158, \mathrm{Bk} \mathrm{V}$, ch. VII), but not necessarily better to strive to get that equality to prevail.

\section{Considering the Future}

We want to end our discussion on a hopeful, future-focused note. For reasons not yet fully understood, democratic political stability around the world increased noticeably during the past decade or two, as Figures 4 and 5 show. Given the strong relationship we have shown here between stability and financial development, the secular decline in political instability in the past decade or two gives reason 
beyond optimistic hope to expect that efforts such as those of the World Bank to initiate financial development by building the right investor protection institutions will not go to waste. In such politically stable settings, their technical finance-enhancing efforts seem, from the data in this paper, most likely to succeed. In unstable political environments, the technical institutions of investor protection are unlikely, our data suggests, to strongly propel financial development. Investor protection efforts may work better in tandem with new World Bank (2007) initiatives that focus on inequality, although those initiatives do not yet link to the possibility of enhancing financial development, nor has the Bank yet analyzed the potential impact of its inequality-reducing initiatives on financial development.

\section{CONCLUSION}

Political instability is important to explaining variation in financial development around the world. Considerable attention has been given in the past decade to explaining which institutions foster or impede financial development, but democratic political stability as a necessary condition, or instability as a serious impediment, has not played the prominent role the results in this paper indicate it deserves, in that ongoing instability may well be as, or more important, than institutional features that have attained prominence. We contribute here to understanding the variance in financial development around the world by showing that variation in political stability has a significant, consistent, and substantial impact over many decades on debt and stock market development. Democratic political instability needs to be added to the small number of core factors that determine financial development around the world.

Political instability's impact on finance is investigated here not just to confirm the intuitively appealing proposition that instability harms financial markets and does so after controlling for the level of a nation's economic development, but to show that it harms finance independently of each prevailing explanation for financial backwardness. Well-regarded conventional measures of political instability such as Alesina and Perotti's (1996) and Banks' (2005) indices of severe political crises such as military coups, political assassinations, and political violence - persistently and significantly predict a wide range of conventional national financial outcomes. These results are robust to investor protection, to legal 
origin, to trade openness, to latitude, and to other measures that have obtained prominence in the past decade. These factors could well be in play and we believe several are, but political stability is there as well and it is there quite significantly and robustly. Financial backwardness is significantly rooted in severe political instability. We thus further extend thinking on the political economy finance, such as that in Acemoglu, Johnson, and Robinson (2001); Rajan and Zingales (2003, 2003a, 2003b); Perotti and von Thadden (2006); Pagano and Volpin (2005); and Roe and Siegel (2009).

That basic finding, which holds up year-by-year over several decades, holds up over four different measures of instability and over multiple measures of financial development. It holds up with measures of instability reconfigured to pick up the extent instability has long-term influence, a longer-term effect that the decay reconfigurations pick up. It holds up in country fixed effects and is supported in instrumental variable regressions, using variables inspired by Engerman and Sokoloff's (2002) work, which have not previously been well-used in the financial development literature. It is persistently robust to legal origin and quite consistent over time. As such, an instability inquiry should open up new policy avenues for financial development and weaken old ones.

In finding a robust channel running from political instability to financial backwardness, we link two major literatures: an economics literature that sees political instability as strongly impeding economic development and a finance literature that sees financial development as strongly propelling economic development. A primary channel from political stability to economic development could well run through financial development.

Such findings could affect development policy. It may be that rough equality, such as that of a broad property-owning middle class, in democratic settings more often than not, induces the political stability that is foundational for financial development. Such democratic and stable polities may better be able to protect property (of which investor protection is a subset) than can less democratic, unstable polities. While development agencies may be unable to deeply change nations in this dimension, their knowing where part of the foundation is should better enable them to choose how to help and to know which nations will most benefit from their help. This property-owning middle-class foundation for 
finance could be as important as the currently prominent characteristics but has not been a major component of recent thinking in academic finance.

Understanding that political stability is foundational for finance - the task we seek to further here

— is fundamental, going far in helping to explain cross-country differences in financial development.

\section{References}

Acemoglu, Daron, Simon Johnson, and James A. Robinson, 2001, The Colonial Origins of Comparative Development: An Empirical Investigation, American Economic Review 91, 1369-1401.

Acemoglu, Daron, Simon Johnson, James Robinson, and Yunyong Thaicharoen, 2003, Institutional Causes, Macroeconomic Symptoms, Volatility, Crises and Growth, Journal of Monetary Economics 50, 49-123.

Acemoglu, Daron, and James A. Robinson, 2006, Economic Origins of Dictatorship and Democracy (Cambridge University Press).

Aisen, Ari, and Francisco José Veiga, 2006, Does Political Instability Lead to Higher Inflation?-A Panel Data Analysis, Journal of Money, Credit and Banking 30, 1379-1389.

Alesina, Alberto, Arnaud Devleeschauwer, William Easterly, Sergio Kurlat, and Romain Wacziarg, 2003, Fractionalization, Journal of Economic Growth 8, 155-94.

Alesina, Alberto, Sule Ozler, Nouriel Roubini, and Phillip Swagel, 1996, Political Instability and Economic Growth, Journal of Economic Growth 1, 189-211.

Alesina, Alberto, and Roberto Perotti, 1996, Income Distribution, Political Instability, and Investment, European Economic Review 40, 1203-1228.

Alesina, Alberto, and Dani Rodrik, 1994, Distributive Politics and Economic Growth, Quarterly Journal of Economics 109, 465-490.

Alesina, Alberto, and Enrico Spolaore, 1997, On the Number and Size of Nations, Quarterly Journal of Economics 102, 1027-56.

Allen, Franklin, Jun Qian and Meijun Qian, 2005, Law, Finance, and Economic Growth in China, Journal of Financial Economics 77, 57-116.

Amadife, Egunam E., 1999, Liberalization and Democratization in Nigeria, Journal of Black Studies 29, 619-645.

Angeles, Luis, 2007, Income Inequality and Colonialism, European Economic Review 51, 1155-1176

Aristotle, 1986, The Politics (Prometheus Books, Buffalo).

Ayyagari, Meghana, Asli Demirgüç-Kunt, and Vojislawv Maksimovic, 2008, How Well Do Institutional Theories Explain Firms' Perceptions of Property Rights?, Review of Financial Studies 21, 1833-1871.

Banks, Arthur S., 2005, Cross-National Time-Series Data Archive [electronic resource] (Arthur S. Banks, Binghamton).

Barro, Robert J. and Jong-Wha Lee, 1994, Data Set for a Panel of 138 Countries, available at http://www.nber.org/pub/barro.lee/reademe.txt.

Beck, Thorsten, Asli Demirgüç-Kunt, and Ross Levine, 2007, Finance, inequality and the poor, Journal of Economic Growth 12, 27-49.

,2000, A New Database on Financial Development and Structure, World Bank Economic Review $14,597-605$.

, 2001, Law, Politics and Finance, World Bank Policy Research Working Paper No. 2585, available at http://ssrn.com/abstract=269118.

Beck, Thorsten, and Ross Levine, 2005, Legal Institutions and Financial Development, in Claude Ménard and Mary M. Shirley, eds.: Handbook of the New Institutional Economics (Springer, Dordrecht, The Netherlands).

Bekaert, Geert, Campbell R. Harvey, and Christian Lundblad, 2005, Does financial liberalization spur growth?, Journal of Financial Economics 77, 3-55.

Bickel, Alexander M., 1962, The Least Dangerous Branch: The Supreme Court in the Bar of Politics (BobbsMerrill, Indianapolis). 
Bobonis, Gustavo J., 2008, Political Institutions, Labor Coercion, and Emergence of Public Schooling: Evidence from the $19^{\text {th }}$ Century Coffee Boom, Working Paper, University of Toronto, March.

Boix, Carles, 2003, Democracy and Redistribution (Cambridge University Press).

Brown, William O., Jr., Richard C.K. Burdekin, and Marc D. Weidenmier, 2006, Volatility in an Era of Reduced Uncertainty: Lessons from Pax Britannica, Journal of Financial Economics 79, 693-707.

Childress, Sarah, 2008, Violence in Kenya Exposes Tribes' Widening Wealth Gap, Wall Street Journal, Jan. 30.

Claessens, Stijn and Enrico Perotti, 2007, Finance and Inequality: Channels and Evidence, Journal of Comparative Economics 35, 748-773.

Coffee, John C., 2001, The Rise of Dispersed Ownership, Yale Law Journal 111, 1-82.

Collier, Paul, 1999, On the Economic Consequences of Civil War, Oxford Economic Papers 51, 168-83 2000, Economic Causes of Civil Conflict and their Implications for Policy, Working Paper, World Bank, June 15.

Djankov, Simeon, Rafael La Porta, Florencio Lopez-de-Silanes, and Andrei Shleifer, 2008, The Law and Economics of Self-Dealing, Journal of Financial Economics, 88, 430-465.

Djankov, Simeon, Caralee McLeish, and Andrei Shleifer, 2007, Private Credit in 129 Countries, Journal of Financial Economics, 84, 299-329.

Dutt, Pushan, and Devashish Mitra, 2008, Inequality and the Instability of Polity and Policy, Economic Journal, $118,1285-1314$.

Dyck, Alexander, and Luigi Zingales, 2004, Private Benefits of Control: An International Comparison, Journal of Finance, 59, 537-600.

Dye, Alan, 2006, The Institutional Framework, in Victor Bulmer-Thomas, John Coatsworth and Roberto Cortés Conde, eds.: The Cambridge Economic History of Latin America. Volume II: The Long Twentieth Century, 169-207 (Cambridge University Press).

Easterly, William, 2001, The Middle Class Consensus and Economic Growth, Journal of Economic Growth 6, 31826.

, 2007, Inequality does cause underdevelopment: insights from a new instrument, Journal of Development Economics 84, 755-776.

Easterly, William, and Ross Levine, 1997, Africa's Growth Tragedy: Policies and Ethnic Divisions, Quarterly Journal of Economics 62, 1203-1250.

Economist, 2007, The World Bank, founded to fight poverty, is searching for the right role in places that need its help less and less, Sept. 8, p. 70.

Engerman, Stanley L., and Kenneth L. Sokoloff, 2002, Factor Endowments, Inequality, and Paths of Development Among New World Economies, Economia 3, 44-71.

, 2005, Institutional and Non-Institutional Explanations of Economic Differences, in Claude Ménard and Mary M. Shirley, eds.: Handbook of New Institutional Economics 639-665 (Springer).

Engerman, Stanley L., Stephen H. Haber, and Kenneth L. Sokoloff, 2000, Inequality, Institutions and Differential Paths of Growth Among New World Economies, in Claude Ménard, ed.: Institutions, Contracts and Organizations: Perspectives from New Institutional Economics 108-134 (Edward Elgar).

FAO, 1977, Trade Yearbook 1976 (Food and Agriculture Organization of the United Nations, Rome).

Fearon, James D. and David D. Laitin, 2003, Ethnicity, Insurgency, and Civil War, American Political Science Review 97, 75-90.

FitzGerald, Edmund V., 1987, An Evaluation of the Economic Costs to Nicaragua of U.S. Aggression, in Rose J. Spalding, ed.: The Political Economy Of Revolutionary Nicaragua 195-213 (Allen \& Unwin, Boston).

Frankel, Jeffrey A., and David Romer, 1999, Does Trade Cause Growth?, American Economic Review 89, $379-399$.

Frankema, Ewout, 2006, The Colonial Origins of Inequality: Exploring the Causes and Consequences of Land Distribution, Working paper (University of Gröningen).

Franks, Julian, Colin Mayer, and Stefano Rossi, 2009, Ownership: Evolution and Regulation, Journal of Financial Studies, 22: 4009-4022.

Glaeser, Edward, 2006, Inequality, in Barry Weingast and Donald Wittman, eds.: Oxford Handbook of Political Economy 624-641.

Glaeser, Edward, Jose Scheinkman, and Andrei Shleifer, 2003, The Injustice of Inequality, Journal of Monetary Economics 50: 199-222. 
Gradstein, Mark, 2007, Inequality, Democracy and the Protection of Property Rights, Economic Journal 117, 252269.

Haber, Stephen, Armando Razo, and Noel Maurer, 2003, The Politics of Property Rights: Political Instability, Credible Commitments, and Economic Growth in Mexico, 1876-1929 (Cambridge University Press).

Huntington, Samuel P., 1991, The Third Wave: Democratization in the Late Twentieth Century (University of Oklahoma).

, 1968, Political Order in Changing Societies (Yale University Press).

IMD, 1999-2004, World Competitiveness Yearbook, (International Institute for Management Development, Lausanne, Switzerland), available at http://www.imd.ch/wcc/yearbook.

King, Robert G., and Ross Levine, 1993, Finance and Growth: Schumpeter Might Be Right, Quarterly Journal of Economics 108, 717-37.

La Porta, Rafael, Florencio Lopez-de-Silanes, and Andrei Shleifer, 2006, What Works in Securities Laws? Journal of Finance 61, 1-32. 2008, The Economic Consequences of Legal Origin, Journal of Economic Literature 46, 285-332.

La Porta, Rafael, Florencio Lopez-de-Silanes, Andrei Shleifer, and Robert W. Vishny, 1997, The Legal Determinants of External Finance, Journal of Finance 52, 1131-1150. , 1998, Law and Finance, Journal of Political Economy 106, 1113-1155.

La Porta, Rafael, Florencio Lopez-de-Silanes, Christian Pop-Eleches, and Andrei Shleifer, 2004, Judicial Checks and Balances, Journal of Political Economy 112, 445-470.

Levine, Ross, 1997, Financial Development and Economic Growth: Views and Agenda, Journal of Economic Literature 35, 688-726.

Lindgren, Göran, 2005, The Economic Costs of Civil Wars, Paper for the Ninth Annual International Conference on Economics and Security, June 23.

Linz, Juan J. and Arturo Valenzuela, eds.: 1994, The Failure of Presidential Democracy (Johns Hopkins University Press).

Marshall, Monty G., and Ted Robert Gurr, Peace and Conflict 2005: A Global Survey of Armed Conflicts, SelfDetermination Movements, and Democracy (University of Maryland, Center for International Development and Conflict Management).

Maurer, Noel, 2002, The Power and the Money: The Mexican Financial System, 1876-1932 (Stanford University Press).

Mayer, Colin, 2008, Trust in Financial Markets, European Financial Management 14, 617-632.

Mishkin, Frederic S., 2006, The Next Great Globalization: How Disadvantaged Nations Can Harness Their Financial Systems to Get Rich (Princeton University Press).

North, Douglass, 1990, Institutions, Institutional Change, and Economic Performance (Cambridge University Press).

Olson, Mancur, 1984, The Rise and Decline of Nations: Economic Growth, Stagflation, and Social Rigidities (Yale University Press).

Outreville, J. François, 1999, Financial Development, Human Capital and Political Stability, United Nations Conference on Trade and Development Discussion Paper No. 142.

Pagano, Marco and Paolo Volpin, 2005, The Political Economy of Corporate Governance, American Economic Review 95, 1005-1030.

Perotti, Enrico C., and Ernst-Ludwig von Thadden, 2006, The Political Economy of Corporate Control and Labor Rents, Journal of Political Economy 114: 145-174.

Perotti, Enrico and Armin Schwienbacher, 2009, The Political Origin of Pension Funding, Journal of Financial Intermediation 18, 384-404.

Perotti, Roberto, 1996, Growth, Income Distribution, and Democracy: What the Data Say, Journal of Economic Growth 1, 149-187.

Rajan, Raghuram G., and Luigi Zingales, 1998, Financial Dependence and Growth, American Economic Review 88, 559-586.

, 2003, The Great Reversals: The Politics of Financial Development in the Twentieth Century, Journal of Financial Economics 69, 5-50.

, 2003a, The Emergence of Strong Property Rights: Speculation from History, NBER Working Paper No. W9478, available at http://papers.ssrn.com/abstract_id=375330. 
, 2003b, Saving Capitalism from the Capitalists (Crown, New York).

Rake, Alan, 1984, Coups without End, New African, April 24-25.

Richardson, Craig J., 2005, The Loss of Property Rights and the Collapse of Zimbabwe, Cato Journal, 25, 541-565

Richardson, J.M., and S.W. Samarasingle, 1991, Measuring the Economic Dimensions of Sri Lanka's Ethnic Conflict, in S.W. Samarasingle \& Reed Coughlan, eds.: Economic Dimensions of Ethnic Conflict 194-223 (St. Martin's Press, London, New York).

Robinson, Joan, 1952, The Rate of Interest and Other Essays (Macmillan, London).

Rock, Edward B., 2001, Encountering the Scarlet Woman of Wall Street, Theoretical Inquiries in Law 2, 237-264.

Rodrik, Dani, 1999, Where Did All the Growth Go? - External Shocks, Social Conflict, and Growth Collapses, Journal of Economic Growth 4, 385-412.

Roe, Mark J., 2003, Political Determinants of Corporate Governance (Oxford University Press).

Roe, Mark J. and Jordan I. Siegel, 2009, Finance and Politics, Journal of Economic Literature 47: 781-800.

Rousseau, Peter L., and Richard Sylla, 2006, Financial revolutions and economic growth, Explorations in Economic History 43, 1-12.

Sanders, David, 1981, Patterns of Political Instability (St. Martin's Press, London, New York).

Stulz, Rene M. and Rohan Williamson, 2003, Culture, Openness, and Finance, Journal of Financial Economics 70: 313-349.

Svensson, Jakob, 1998, Investment, Property Rights and Political Instability: Theory and Evidence, European Economic Review 42, 1317-1341.

Sylla, Richard, Richard Tilly, and Gabriella Tortella, 1999, The State, the Financial Systems and Economic Modernization (Cambridge University Press).

Taylor, Charles Lewis, and David A. Jodice, 1983, World Handbook of Political and Social Indicators, 3d ed. (Yale University Press).

Treisman, Daniel, 2000, The Causes of Corruption: A Cross National Study, Journal of Public Economics 76, 399457.

Van de Vliert, Evert, Shalom H. Schwartz, Spike E. Huismans, Geert Hofstede, and Serge Daan, 1999, Temperature, Cultural Masculinity, and Domestic Political Violence, Journal of Cross-Cultural Psychology 30, 291-314.

Voth, Hans-Joachim, 2002, Why Was Stock Market Volatility so High During the Great Depression? Evidence from 10 Countries during the Interwar Period, Centre for Economic Policy Research Working Paper No. 3254, available at http://ssrn.com/abstract_id=306770.

Whittington, Keith E., 2005, "Interpose Your Friendly Hand": Political Supports for the Exercise of Judicial Review by the United States Supreme Court, American Political Science Review 99, 583-596.

World Bank, 2007, World Bank Independent Evaluation Group, Development Results in Middle-Income Countries: An Evaluation of the World Bank's Support, available at http://worldbank.org/ieg.

,2006, Institutional Foundations for Financial Markets, available at http://siteresources.worldbank.org /inttopaccfinser/Resources/Institutional.pdf.

You, Jong-sung, and Sanjeev Khagram, 2005, A Comparative Study of Inequality and Corruption, American Sociological Review 70, 136-157. 
Table 1. Description of Variables

\section{$\underline{\text { Political instability measures }}$} period 1960-1982. Principal component analysis was used to construct their index, based on a nation's

IMD instability measure

World Economic Forum instability measure

Legal Origin

Size of the Middle Class

Gini coefficient

Ethnic Fractionalization

Natural Geographic Openness - constructed trade share

Latitude

Log of GDP per capita

Anti-Self Dealing Index

Djankov Anti-Director Rights Index

Creditor Rights Index

Land Inequality

Rice, sugar, cocoa, coffee, and tobacco export/total agricultural exports in 1975
The Sociopolitical Instability (SPI) index measures the overall, average political instability by country for the number of politically-motivated assassinations during that time period, the number of people killed in domestic mass violence (as a percentage of the nation's total population), the number of successful and attempted coups, and a categorical variable for whether the nation is a democracy or a dictatorship, set at 1 for democracies, 0.5 for semi-democracies, and 0 otherwise.

Index created by counting any rapidly developing situation that threatens to bring the downfall of the present regime. Underlying data is from the New York Times, as assembled by Banks (2005). We used a moving index with a $1 \%$ annual decay rate. The decay index takes the current year's observation of political instability from Banks' data, adds to that .99 of the prior year's instability observation, then adds $.99^{2}$ of the observation from two year's prior, then adds $.99^{3}$ from three year's prior, and so for all available annual observations of instability from Banks, which go back approximately 30 years for the most recent observations. We used alternative decay rates of $5 \%$ and $10 \%$, using analogous constructions.

Lausanne-bassed International Institute of Managerial Development's measure of political instability for recent years, based on executive surveys. We averaged the annual results for the 1999-2003 and 1999-2004 periods that matched the available years for the financial development indicators.

\section{Banking and private debt outcomes}

\section{Financial outcomes}

Equals the amount of domestic credit provided by the banking sector, divided by GDP. It includes the banks credit position in relation to government-owned firms and government entities. For a few countries, most prominently Saudi Arabia and Botswana, credit from the government entities and firms to the banking sector is large enough to offset the banking sector's credits to the private sector. Data available for years 1965-2004.

Equals the total amount of credit to the private sector divided by GDP. Data available for years 1965-2004.

\section{Equity market development outcomes}

Equals stock market capitalization divided by GDP. Data available for years 1988-2004

Equals stock market capitalization divided by GDP. Data available for years 1976-2003.

\section{Controls and instruments}

Alesina and Perotti (1996: 1207)

Calculated from Banks, CNTS (2005)

World Competitiveness Yearbook (19992004), available at http://www.imd.ch/wcc/yearbook

World Economic Forum's Global

Competitiveness Report, various

World Bank, WDI (2005: Table 5.5)

World Bank, WDI (2005: Table 5.1)

World Bank, WDI (2005: Table 5.4)

Beck, Demirgüç-Kunt, and Levine (2000)

LLSV (1996: 1130-31), CIA Factbook (2006)

Index created by coding countries by legal origin, into one of five categories - French Civil Law, Common Law, Scandinavian Law, Socialist Law, and Germany Civil Law. Any data missing from La Porta et al. is coded using the CIA Factbook.

Indexed by the relative proportion of national income going to the middle class (defined as the third and fourth quintiles) in 1960 or the most proximate annual observation available after 1960.

Index of income inequality measured by the Gini coefficients in the WIDER World Income Inequality Database for years 1970-2000.

Index created by finding the probability that two randomly selected members of a population be of the same ethnic groups. The definition of ethnicity combines racial and linguistic characteristics.

Index measures the trade share of a country and takes into account the following variables: real income per person; international trade (measured as exports plus imports); log population and log area of countries, and; dummy variables for whether countries are landlocked and whether they have a common border.

Index of latitude, measured by distance from the equator

Data on GDP per capita in constant U.S. dollars for the years 1965-2004 came from the World Bank's Word Development Indicators (WDI) database.

Index computed by weighting: (1) the approval required by disinterested shareholders; (2) disclosures required by buyers; (3) whether independent financial review is required; (4) the \% of shareholders who are required for standing to sue; (5) the quality of ex-post periodic disclosures; (6) the ease of rescinding a transaction ex-post;

Updating and correction of earlier index computed by aggregating shareholder rights. Covers the following six areas: (1) vote by mail; (2) obstacles to the actual exercise of the right to vote (i.e., the requirement that shares be deposited before the shareholders' meeting); (3) minority representation on the Board of Directors through be deposited before the shareholders' meeting); (3) minority representation on the Board of Directors through
cumulative voting or proportional representation; (4) an oppressed minority mechanism to seek redress in case cumulative voting or proportional representation; (4) an oppressed minority mechanism to seek redress in case
of expropriation; (5) pre-emptive rights to subscribe to new securities issued by the company; and (6) right to call a special shareholder meeting.

Index measures four powers of secured lenders in bankruptcy. First, whether there are restrictions, such as creditor consent, when a debtor files for reorganization. Second, whether secured creditors are able to seize their collateral after the petition for reorganization is approved, in other words whether there is no 'automatic stay' or 'asset freeze' imposed by the court. Third, whether secured creditors are paid first out of the proceeds of liquidating a bankrupt firm. Finally, whether an administrator, and not management, is responsible for running the business during the reorganization. A value of one is added to the index when a country's laws and regulations provide each of these powers to secured lenders. The creditor rights index aggregates the scores and varies between 0 (poor creditor rights) and 4 (strong creditor rights).

Index compiled by calculating the Gini coefficients of inequality of land distribution. Gini analysis is performed on the decile distributions of the total number of land holdings (farms), and the total amount of agricultural land (excluding communal pastures and forests).

Equals the proportion of total agricultural exports accounted for by each agricultural item in 1975 .

Index taking 1 if the mean temperature of the capital city is above 32 degree celsius, 0 otherwise. Temperatures were taken from the sixth edition of the National Geographic Atlas of the World (Garver, Payne, \& Canby, 1990).

\section{Alesina and Perotti (1996: 1207)}

World Institute for Development Economics Research (WIIDER)

Alesina, Devleeschauwer, Easterly, Kurlat, and Wacziarg (2003: 159-160)

Frankel and Romer (1999)

You and Khagram (2005) World Bank, WDI (2005: Table 4.2)

Djankov et al. (2005)

Djankov et al. (2005)

Djankov et al. (2004)

Frankema (2006: 7)

FAO Trade Yearbook (1977)

Van de Viliert (1999: 295-96) 
The following table takes the cross-sectional sample for our full models for each year and presents the means for the key variables of interest. The SPI index is a time-invariant index, and hence the value is the same across the years below. The political instability decay index, in contrast, is time-varying, and the summary statistics below show that there was in fact a secular reduction in political instability over the course of the 1990s and early 2000s. Because the sample from 1988-2003 is increasing in its coverage of poor countries over time (as they begin to have equity markets), the resulting mean log GDP per capita thus is not increasing over time.

Panel 1. A Focus on Debt Markets (1965-1989)

\begin{tabular}{|c|c|c|c|c|c|c|c|c|c|c|c|c|c|c|c|c|c|c|}
\hline \multirow[t]{2}{*}{ year } & \multicolumn{4}{|c|}{ Bank Credit/GDP } & \multicolumn{4}{|c|}{ Private Credit/GDP } & \multicolumn{4}{|c|}{$\begin{array}{l}\text { Alesina-Perotti political instability } \\
\text { index (a time-invariant variable) }\end{array}$} & \multicolumn{4}{|c|}{$\begin{array}{l}\text { Log GDP per capita in constant U.S. } \\
\text { dollars }\end{array}$} & \multicolumn{2}{|c|}{ Number of Observations } \\
\hline & Mean & Std.Dev. & Min & Max & Mean & Std.Dev. & Min & Max & Mean & Std.Dev. & Min & Max & Mean & Std.Dev. & Min & Max & Bank Credit & Private credit \\
\hline 1965 & 32.3 & 23.8 & -6.0 & 114.0 & 25.3 & 21.9 & $\overline{4.0}$ & $\overline{101.0}$ & -0.19 & 11.93 & -11.76 & 44.19 & 7.5 & 1.5 & $\overline{4.7}$ & $\overline{10.0}$ & 57 & 58 \\
\hline 1966 & 32.3 & 23.6 & -2.0 & 113.0 & 25.5 & 21.8 & 5.0 & 98.0 & -0.39 & 11.82 & -11.76 & 44.19 & 7.5 & 1.5 & 4.8 & 10.0 & 59 & 59 \\
\hline 1967 & 33.8 & 23.7 & 3.0 & 114.0 & 26.4 & 22.1 & 5.0 & 102.0 & -0.39 & 11.82 & -11.76 & 44.19 & 7.5 & 1.5 & 4.8 & 10.0 & 59 & 59 \\
\hline 1968 & 34.8 & 23.8 & 5.0 & 116.0 & 27.0 & 22.2 & 5.0 & 103.0 & -0.34 & 11.73 & -11.76 & 44.19 & 7.5 & 1.5 & 4.8 & 10.0 & 60 & 60 \\
\hline 1969 & 35.9 & 24.0 & 0.0 & 118.0 & 28.0 & 22.4 & 5.0 & 103.0 & -0.34 & 11.73 & -11.76 & 44.19 & 7.6 & 1.5 & 4.8 & 10.1 & 60 & 60 \\
\hline 1970 & 36.5 & 26.1 & -2.0 & 126.0 & 28.6 & 23.9 & 1.0 & 105.0 & -0.34 & 11.73 & -11.76 & 44.19 & 7.6 & 1.5 & 4.8 & 10.1 & 60 & 60 \\
\hline 1971 & 39.0 & 26.6 & 4.0 & 139.0 & 30.9 & 24.9 & 1.0 & 116.0 & -0.52 & 11.72 & -11.76 & 44.19 & 7.7 & 1.5 & 4.9 & 10.2 & 61 & 61 \\
\hline 1972 & 41.3 & 27.8 & 4.0 & 151.0 & 32.3 & 26.1 & 1.0 & 125.0 & -0.52 & 11.72 & -11.76 & 44.19 & 7.7 & 1.5 & 5.0 & 10.2 & 61 & 62 \\
\hline 1973 & 41.9 & 27.9 & 4.0 & 149.0 & 32.9 & 26.1 & 1.0 & 124.0 & -0.52 & 11.72 & -11.76 & 44.19 & 7.7 & 1.6 & 4.9 & 10.2 & 61 & 62 \\
\hline 1974 & 41.4 & 27.3 & -2.0 & 145.0 & 32.9 & 25.2 & 1.0 & 119.0 & -0.39 & 11.58 & -11.76 & 44.19 & 7.7 & 1.6 & 5.0 & 10.2 & 63 & 63 \\
\hline 1975 & 45.6 & 28.2 & 4.0 & 155.0 & 34.8 & 25.6 & 1.0 & 122.0 & -0.49 & 11.42 & -11.76 & 44.19 & 7.7 & 1.5 & 5.0 & 10.2 & 65 & 65 \\
\hline 1976 & 45.9 & 28.4 & 6.0 & 161.0 & 35.2 & 25.3 & 1.0 & 122.0 & -0.63 & 11.39 & -11.76 & 44.19 & 7.7 & 1.5 & 5.0 & 10.1 & 66 & 66 \\
\hline 1977 & 47.4 & 28.7 & 5.0 & 163.0 & 35.1 & 24.8 & 1.0 & 120.0 & -0.63 & 11.39 & -11.76 & 44.19 & 7.7 & 1.5 & 5.0 & 10.2 & 66 & 66 \\
\hline 1978 & 50.7 & 30.3 & 4.0 & 169.0 & 38.0 & 26.0 & 1.0 & 119.0 & -0.62 & 11.47 & -11.76 & 44.19 & 7.7 & 1.5 & 5.1 & 10.2 & 65 & 65 \\
\hline 1979 & 53.1 & 30.8 & 1.0 & 173.0 & 39.3 & 26.1 & 1.0 & 121.0 & -0.63 & 11.39 & -11.76 & 44.19 & 7.8 & 1.5 & 5.1 & 10.2 & 66 & 65 \\
\hline 1980 & 54.4 & 30.6 & 1.0 & 178.0 & 39.4 & 26.3 & 1.0 & 122.0 & -0.63 & 11.39 & -11.76 & 44.19 & 7.8 & 1.6 & 5.0 & 10.2 & 66 & 65 \\
\hline 1981 & 57.6 & 31.7 & 9.0 & 183.0 & 40.8 & 26.4 & 1.0 & 125.0 & -0.63 & 11.39 & -11.76 & 44.19 & 7.8 & 1.6 & 5.0 & 10.3 & 66 & 65 \\
\hline 1982 & 61.8 & 34.0 & 4.0 & 192.0 & 42.8 & 28.3 & 1.0 & 130.0 & -0.63 & 11.39 & -11.76 & 44.19 & 7.7 & 1.6 & 5.0 & 10.2 & 66 & 65 \\
\hline 1983 & 63.4 & 35.6 & -1.0 & 201.0 & 43.4 & 28.8 & 1.0 & 135.0 & -0.63 & 11.39 & -11.76 & 44.19 & 7.7 & 1.6 & 5.0 & 10.2 & 66 & 65 \\
\hline 1984 & 63.0 & 40.7 & -8.0 & 232.0 & 43.0 & 29.9 & 1.0 & 137.0 & -0.63 & 11.39 & -11.76 & 44.19 & 7.8 & 1.6 & 5.0 & 10.3 & 66 & 65 \\
\hline 1985 & 60.7 & 39.3 & -20.0 & 207.0 & 42.4 & 30.4 & 1.0 & 139.0 & -0.63 & 11.39 & -11.76 & 44.19 & 7.8 & 1.6 & 5.0 & 10.3 & 66 & 65 \\
\hline 1986 & 61.9 & 39.6 & -38.0 & 216.0 & 43.9 & 32.4 & 5.0 & 145.0 & -0.56 & 11.46 & -11.76 & 44.19 & 7.8 & 1.6 & 5.0 & 10.3 & 65 & 64 \\
\hline 1987 & 61.0 & 40.9 & -47.0 & 228.0 & 43.4 & 33.4 & 3.0 & 160.0 & -0.63 & 11.39 & -11.76 & 44.19 & 7.8 & 1.6 & 4.9 & 10.3 & 66 & 65 \\
\hline 1988 & 62.9 & 43.8 & -41.0 & 234.0 & 45.2 & 36.5 & 2.0 & 167.0 & -0.63 & 11.30 & -11.76 & 44.19 & 7.8 & 1.6 & 4.9 & 10.3 & 67 & 66 \\
\hline 1989 & 62.4 & 45.4 & -41.0 & 238.0 & 47.0 & 37.9 & 5.0 & 173.0 & -0.57 & 11.37 & -11.76 & 44.19 & 7.8 & 1.6 & 4.9 & 10.4 & 66 & 65 \\
\hline 1990 & 61.1 & 43.9 & -46.0 & 238.0 & 46.5 & 39.2 & 3.0 & 176.0 & -0.63 & 11.30 & -11.76 & 44.19 & 7.8 & 1.6 & 4.9 & 10.4 & 67 & 66 \\
\hline
\end{tabular}

Note: The summary statistics for the Alesina-Perotti SPI and for Log GDP per capita are based on the observations also in the Bank Credit/GDP sample. Bank Credit/GDP includes bank loansfrom government entities and government-owned firms to the banking sector. For several nations, with Botswana foremost, credit from the government entities to the banking sector is large enough to offset the banking sector's own lending, yielding a single negative observation. There are 12 such negative observations in the total of 1656 observations. We re-ran the two sets of specifications that use bank loans/GDP (in Tables 3 and 10 ) without the negative observations, to verify that these were not driving the largely significant, negative results for political instability. They do not. Those results are reported in the appendix.

Panel 2. A Focus on Equity Markets (1988-2003)

\begin{tabular}{|c|c|c|c|c|c|c|c|c|c|c|c|c|c|c|c|c|c|c|}
\hline \multirow[t]{2}{*}{ year } & \multicolumn{4}{|c|}{$\begin{array}{l}\text { World Bank Stock Market } \\
\text { Capitalization/GDP (measured as a } \\
\text { percentage of GDP) }\end{array}$} & \multicolumn{4}{|c|}{$\begin{array}{l}\text { Beck et al. Stock Market Capitalization/GDP } \\
\text { (measured as a ratio) }\end{array}$} & \multicolumn{4}{|c|}{$\begin{array}{l}\text { Political Instability Decay Index (a } \\
\text { time-varying variable based on Banks' } \\
\text { political instability database) }\end{array}$} & \multicolumn{4}{|c|}{$\begin{array}{l}\text { Log GDP per capita in constant U.S. } \\
\text { dollars }\end{array}$} & \multicolumn{2}{|c|}{ Number of Observations } \\
\hline & Mean & Std.Dev. & Min & Max & Mean & Std.Dev. & Min & Max & Mean & Std.Dev. & Min & Max & Mean & Std.Dev. & Min & Max & World Bank & Beck et al. \\
\hline 1983 & & & & & 0.20 & 0.28 & 0.001 & 1.34 & 10.7 & 8.2 & 0.7 & 38.6 & 8.6 & 1.3 & 5.5 & 10.2 & 37 & \\
\hline 1984 & & & & & 0.21 & 0.32 & 0.001 & 1.62 & 10.3 & 8.0 & 0.0 & 36.7 & 8.6 & 1.3 & 5.5 & 10.3 & 37 & \\
\hline 1985 & & & & & 0.26 & 0.43 & 0.001 & 2.43 & 9.4 & 7.8 & 0.0 & 35.9 & 8.7 & 1.3 & 5.6 & 10.3 & 37 & \\
\hline 1986 & & & & & 0.31 & 0.56 & 0.001 & 3.33 & 8.9 & 7.4 & 0.0 & 35.1 & 8.6 & 1.4 & 5.6 & 10.3 & 39 & \\
\hline 1987 & & & & & 0.37 & 0.74 & 0.001 & 4.48 & 9.2 & 7.5 & 0.8 & 36.7 & 8.7 & 1.4 & 5.6 & 10.3 & 39 & \\
\hline 1988 & 44.2 & 92.0 & 0.0 & 549.0 & 0.41 & 0.84 & 0.002 & 5.09 & 8.8 & 7.6 & 0.8 & 35.9 & 8.7 & 1.4 & 5.7 & 10.3 & 36 & 38 \\
\hline 1989 & 37.7 & 35.9 & 2.0 & 148.0 & 0.41 & 0.58 & 0.003 & 3.23 & 8.9 & 7.7 & 0.8 & 36.8 & 8.7 & 1.4 & 5.7 & 10.4 & 38 & 38 \\
\hline 1990 & 30.3 & 31.0 & 2.0 & 123.0 & 0.31 & 0.32 & 0.003 & 1.21 & 8.0 & 7.3 & 0.8 & 36.7 & 8.6 & 1.4 & 5.8 & 10.4 & 43 & 44 \\
\hline 1991 & 31.6 & 32.6 & 0.0 & 140.0 & 0.31 & 0.31 & 0.004 & 1.27 & 7.2 & 6.7 & 0.0 & 34.1 & 8.4 & 1.5 & 5.4 & 10.4 & 50 & 44 \\
\hline 1992 & 29.4 & 31.0 & 0.0 & 159.0 & 0.29 & 0.30 & 0.002 & 1.34 & 7.3 & 6.9 & 0.0 & 38.8 & 8.4 & 1.4 & 5.4 & 10.5 & 52 & 51 \\
\hline 1993 & 43.8 & 53.9 & 0.0 & 329.0 & 0.37 & 0.43 & 0.017 & 2.42 & 7.3 & 6.6 & 0.0 & 38.7 & 8.4 & 1.4 & 5.4 & 10.5 & 54 & 53 \\
\hline 1994 & 42.9 & 50.4 & 0.0 & 267.0 & 0.43 & 0.50 & 0.003 & 2.83 & 6.9 & 6.5 & 0.0 & 37.4 & 8.4 & 1.5 & 5.3 & 10.5 & 58 & 54 \\
\hline 1995 & 40.7 & 49.1 & 0.0 & 251.0 & 0.40 & 0.47 & 0.002 & 2.42 & 6.8 & 6.4 & 0.0 & 36.5 & 8.3 & 1.5 & 5.3 & 10.5 & 62 & 59 \\
\hline 1996 & 43.4 & 53.1 & 0.0 & 305.0 & 0.43 & 0.50 & 0.002 & 2.65 & 6.6 & 6.4 & 0.0 & 38.2 & 8.4 & 1.4 & 5.3 & 10.5 & 63 & 60 \\
\hline 1997 & 41.9 & 46.1 & 0.0 & 219.0 & 0.44 & 0.48 & 0.000 & 2.03 & 6.1 & 6.4 & 0.0 & 39.0 & 8.3 & 1.5 & 5.0 & 10.5 & 73 & 71 \\
\hline 1998 & 45.6 & 50.4 & 1.0 & 256.0 & 0.45 & 0.48 & 0.008 & 2.42 & 5.9 & 6.5 & 0.0 & 39.6 & 8.2 & 1.5 & 5.0 & 10.6 & 76 & 74 \\
\hline 1999 & 60.6 & 66.5 & 1.0 & 273.0 & 0.55 & 0.58 & 0.009 & 2.68 & 5.7 & 6.2 & 0.0 & 37.1 & 8.3 & 1.5 & 5.0 & 10.6 & 76 & 74 \\
\hline 2000 & 54.7 & 61.2 & 1.0 & 322.0 & 0.61 & 0.66 & 0.008 & 3.11 & 5.7 & 6.3 & 0.0 & 36.7 & 8.3 & 1.5 & 5.0 & 10.7 & 75 & 74 \\
\hline 2001 & 47.3 & 47.9 & 1.0 & 250.0 & 0.54 & 0.55 & 0.009 & 2.70 & 4.9 & 5.6 & 0.0 & 32.7 & 8.2 & 1.6 & 4.9 & 10.7 & 77 & 72 \\
\hline 2002 & 42.9 & 40.6 & 1.0 & 200.0 & 0.47 & 0.44 & 0.011 & 2.02 & 4.9 & 5.7 & 0.0 & 32.3 & 8.3 & 1.5 & 5.4 & 10.7 & 77 & 73 \\
\hline 2003 & 51.1 & 47.2 & 1.0 & 226.0 & 0.47 & 0.42 & 0.011 & 2.08 & 4.8 & 5.6 & 0.0 & 31.5 & 8.3 & 1.5 & 5.4 & 10.8 & 78 & 68 \\
\hline
\end{tabular}

Note: The cross-sectional samples for years 1983-1987 for the political instability decay index and log GDP per capita variables are based on the full model regressions in which the Beck et al. stock market development is the dependent variable. For years 1988-2003, the cross-sectional samples for the political instability decay index and log GDP per capita variables are based on the full models in which the World Bank stock market development measure is the dependent variable. 
Table 3. Time Persistent Correlations Between Political Instability and Credit Market Size (1965-1990)

This table, in Panel A, presents the results of cross-sectional OLS regressions in which bank credit is the dependent variable and the instability measures, legal origin dummies, constructed trade share, and log GDP per capita are independent variables. The German Civil Law dummy is the omitted dummy variable. The instability measure is Alesina-Perotti's sociopolitical instability (SPI) index, which runs through 1982, Although the SPI index and its underlying source data end in 1982, we regress debt outcomes on the measure for the rest of that decade to ascertain whether it has continuing predictive value. We run similar OLS regressions with other credit measures, such a total private credit and bond debt, in the Appendix. Results are similar. There were no Socialist Law countries with available SPI data. T-statistics appear to the right of each coefficient, with statistical significance is assessed based on robust standard errors. ${ }^{\star \star \star}$ indicates significance at the .01 level, ** indicates significance at the .05 level, and * indicates significance at the .10 level.

Panel A: Bank Credit/GDP as predicted by political instability, legal origin, trade, and log GDP per capita, year-by-year cross-sections

\begin{tabular}{|c|c|c|c|c|c|c|c|c|c|c|c|c|c|c|c|}
\hline \multirow{2}{*}{ Year of Data } & \multicolumn{2}{|l|}{ SPI Index } & \multicolumn{2}{|c|}{ French Civil Law } & \multicolumn{2}{|c|}{ Common Law } & \multicolumn{2}{|c|}{ Scandinavian Civil Law } & \multicolumn{4}{|c|}{ Constructed Trade Share Log of GDP per capita } & \multirow[b]{2}{*}{ Obs } & \multirow[b]{2}{*}{$\mathrm{p}$ value } & \multirow[b]{2}{*}{ R-squared } \\
\hline & Coefficient & t-statistic & Coefficient & t-statistic & Coefficient & t-statistic & Coefficient & t-statistic & Coefficient & t-statistic & Coefficient & t-statistic & & & \\
\hline 1965 & $-0.426^{\star \star \star}$ & -2.93 & $-34.473^{\star \star}$ & -2.22 & $-36.762^{\star \star}$ & -2.32 & $-27.287^{*}$ & -1.71 & $-0.356^{\star \star}$ & -2.43 & $7.471^{\star \star \star}$ & 4.04 & 57 & 0.000 & 0.618 \\
\hline 1966 & $-0.419^{\star \star \star}$ & -2.85 & $-35.590^{\star \star}$ & -2.36 & $-37.620^{\star \star}$ & -2.50 & $-25.970^{*}$ & -1.70 & $-0.344^{\star \star}$ & -2.48 & $7.169^{\star \star \star}$ & 4.06 & 59 & 0.000 & 0.614 \\
\hline 1967 & $-0.446^{\star \star \star}$ & -3.02 & $-33.924^{\star \star}$ & -2.25 & $-35.921^{\star \star}$ & -2.38 & -25.036 & -1.63 & $-0.369^{\star \star \star}$ & -2.66 & $7.374^{\star \star \star}$ & 4.19 & 59 & 0.000 & 0.625 \\
\hline 1968 & $-0.386^{\star \star}$ & -2.60 & $-32.734^{\star \star}$ & -2.10 & $-33.840^{\star *}$ & -2.18 & -23.427 & -1.44 & $-0.321^{\text {** }}$ & -2.34 & $7.585^{\star \star \star}$ & 4.23 & 60 & 0.000 & 0.595 \\
\hline 1969 & $-0.395^{\star \star \star}$ & -2.68 & $-32.145^{\star *}$ & -2.08 & $-34.564^{\star \star}$ & -2.24 & -23.978 & -1.43 & $-0.294^{\star *}$ & -2.03 & $7.649^{\star \star \star}$ & 4.35 & 60 & 0.000 & 0.595 \\
\hline 1970 & $-0.356^{\star \star}$ & -2.34 & $-45.695^{\star \star}$ & -2.63 & $-47.148^{\star \star \star}$ & -2.68 & $-38.647^{\star \star}$ & -2.16 & $-0.368^{\star \star}$ & -2.04 & $8.067^{\star \star \star}$ & 4.44 & 60 & 0.000 & 0.624 \\
\hline 1971 & $-0.347^{\star \star}$ & -2.16 & $-38.263^{\star \star}$ & -2.23 & $-39.935^{\star \star}$ & -2.27 & $-31.592^{\star}$ & -1.79 & $-0.411^{\star \star}$ & -2.02 & $8.023^{\star \star \star}$ & 4.15 & 61 & 0.000 & 0.593 \\
\hline 1972 & $-0.376^{\star}$ & -2.00 & $-38.670^{\star \star}$ & -2.13 & $-41.095^{\star \star}$ & -2.23 & $-34.512^{\star}$ & -1.84 & $-0.502^{\star \star}$ & -2.41 & $8.435^{\star \star \star}$ & 4.16 & 61 & 0.000 & 0.587 \\
\hline 1973 & $-0.401^{\star \star}$ & -2.47 & $-35.316^{\star \star}$ & -2.01 & $-37.768^{\star \star}$ & -2.12 & $-33.950^{\star}$ & -1.84 & $-0.482^{\star \star}$ & -2.24 & $8.794^{\star \star \star}$ & 4.68 & 61 & 0.000 & 0.585 \\
\hline 1974 & $-0.523^{\star \star \star}$ & -3.70 & -27.381 & -1.60 & $-30.231^{*}$ & -1.71 & -29.144 & -1.62 & -0.333 & -1.36 & $8.691^{\star \star \star}$ & 4.74 & 63 & 0.000 & 0.564 \\
\hline 1975 & $-0.580^{\star \star \star}$ & -3.66 & -28.636 & -1.47 & -30.744 & -1.55 & $-34.028^{*}$ & -1.74 & -0.075 & -0.26 & $8.157^{\star \star \star}$ & 4.20 & 65 & 0.000 & 0.505 \\
\hline 1976 & $-0.551^{\star \star \star *}$ & -3.03 & $-33.921^{\star}$ & -1.73 & $-36.099^{*}$ & -1.81 & $-39.760^{\star *}$ & -2.03 & -0.084 & -0.31 & $8.232^{\star \star \star}$ & 4.07 & 66 & 0.000 & 0.529 \\
\hline 1977 & $-0.495^{\star \star \star}$ & -3.01 & $-35.679^{*}$ & -1.82 & $-35.987^{*}$ & -1.76 & $-41.779^{\star \star}$ & -2.08 & -0.028 & -0.09 & $8.537^{\star \star \star}$ & 4.12 & 66 & 0.000 & 0.529 \\
\hline 1978 & $-0.553^{\star \star \star}$ & -3.06 & $-35.193^{*}$ & -1.74 & $-37.807^{*}$ & -1.79 & $-46.302^{\star *}$ & -2.16 & 0.052 & 0.17 & $8.731^{\star \star \star}$ & 3.99 & 65 & 0.000 & 0.520 \\
\hline 1979 & $-0.602^{\star \star \star}$ & -3.28 & $-38.091^{\star}$ & -1.84 & $-39.028^{\star}$ & -1.78 & $-48.623^{\star \star}$ & -2.20 & 0.133 & 0.38 & $8.162^{\star \star \star}$ & 3.67 & 66 & 0.000 & 0.509 \\
\hline 1980 & $-0.645^{\star \star \star}$ & -3.48 & $-42.266^{\star \star}$ & -2.02 & $-44.521^{\star \star}$ & -2.01 & $-52.689^{\star \star}$ & -2.41 & 0.101 & 0.29 & $7.037^{\star \star \star}$ & 3.25 & 66 & 0.000 & 0.501 \\
\hline 1981 & $-0.626^{\star \star \star}$ & -3.50 & $-42.776^{\star \star}$ & -2.03 & $-45.446^{\star \star}$ & -2.04 & $-53.376^{\star \star}$ & -2.35 & 0.058 & 0.16 & $7.067^{\star \star \star}$ & 3.17 & 66 & 0.000 & 0.467 \\
\hline 1982 & -0.387 & -1.62 & $-45.440^{\star *}$ & -2.00 & $-47.332^{\star}$ & -1.95 & $-59.860^{* *}$ & -2.50 & 0.054 & 0.13 & $8.792^{\star \star \star}$ & 3.51 & 66 & 0.000 & 0.439 \\
\hline 1983 & $-0.477^{\star \star}$ & -2.34 & $-45.429^{\star}$ & -1.82 & $-46.294^{\star}$ & -1.71 & $-61.213^{\star \star}$ & -2.41 & 0.164 & 0.33 & $8.702^{\star \star \star}$ & 3.28 & 66 & 0.000 & 0.427 \\
\hline 1984 & $-0.464^{\star \star}$ & -2.11 & $-47.850^{*}$ & -1.77 & -45.301 & -1.50 & $-62.917^{\star \star}$ & -2.38 & 0.383 & 0.58 & $9.947^{\star \star \star}$ & 3.35 & 66 & 0.000 & 0.409 \\
\hline 1985 & $-0.680^{\star \star}$ & -2.02 & $-55.798^{\star \star}$ & -2.19 & $-52.708^{\star}$ & -1.93 & $-63.724^{\star \star}$ & -2.50 & 0.245 & 0.52 & $7.992^{\star \star \star}$ & 2.91 & 66 & 0.000 & 0.445 \\
\hline 1986 & $-0.875^{\star \star}$ & -2.38 & $-57.210^{\star \star}$ & -2.25 & $-59.676^{\star \star}$ & -2.21 & $-59.983^{\star \star}$ & -2.28 & -0.085 & -0.23 & $7.191^{\star \star \star \star}$ & 2.83 & 65 & 0.000 & 0.463 \\
\hline 1987 & $-0.677^{\star}$ & -1.73 & $-62.937^{\star \star}$ & -2.34 & $-63.843^{\star \star}$ & -2.26 & $-67.467^{\star \star}$ & -2.51 & -0.124 & -0.36 & $9.483^{\star \star \star}$ & 3.65 & 66 & 0.000 & 0.506 \\
\hline 1988 & $-0.702^{*}$ & -1.70 & $-58.444^{\star \star}$ & -2.11 & $-58.095^{\star \star}$ & -2.03 & $-65.953^{\star \star}$ & -2.37 & -0.147 & -0.37 & $11.838^{\star \star \star}$ & 4.72 & 67 & 0.000 & 0.516 \\
\hline 1989 & -0.689 & -1.63 & $-60.794^{\star \star}$ & -2.16 & $-62.654^{\star \star}$ & -2.18 & $-66.418^{\star \star}$ & -2.36 & -0.298 & -0.73 & $12.772^{\star \star \star}$ & 5.00 & 66 & 0.000 & 0.547 \\
\hline 1990 & -0.335 & -1.17 & $-69.062^{\star \star}$ & -2.57 & $-63.227^{\star *}$ & -2.28 & $-62.886^{\star *}$ & -2.14 & -0.241 & -0.68 & $13.747^{\star \star \star}$ & 6.88 & 67 & 0.000 & 0.599 \\
\hline
\end{tabular}

In Panel B first model, we pool the above panel's 25 years of cross-sections and add a trend variable. We regress debt market development on the SPI Index, a trend variable, and other controls. Because the SPI Index is time-invariant, country fixed effects cannot be used. Robust standard errors clustered at the country level are presented below each coefficient in brackets. Model 2 pools the quartercentury of cross-sections (reported in the appendix) with private credit/GDP as the dependent variable. The political instability index is significant at the 01 level in Model 1 and at the .05 level in Model 2.

Panel B: Explaining Debt in a Quarter-Century Panel with the Addition of a Trend

\begin{tabular}{lcc} 
& $\begin{array}{c}\text { DV: Bank } \\
\text { Credit/GDP } \\
(1965-1990)\end{array}$ & $\begin{array}{c}\text { DV: Private } \\
\text { Credit/GDP } \\
(1965-1990)\end{array}$ \\
\hline Independent Variable & Model 1 & Model 2 \\
\hline SPI Index & $-0.511^{\star \star \star}$ & $-0.317^{\star \star}$ \\
Constructed Trade Share & {$[0.167]$} & {$[0.146]$} \\
& -0.118 & -0.120 \\
Log of GDP per capita & {$[0.259]$} & {$[0.187]$} \\
& $8.902^{\star \star}$ & $9.158^{\star \star \star}$ \\
Trend variable included? & {$[1.755]$} & {$[1.853]$} \\
Legal orign included? & Yes & Yes \\
Country fixed effects included? No & Yes \\
Obs & 1656 & No \\
p value & 0.000 & 1645 \\
R squared & 0.537 & 0.000 \\
\hline
\end{tabular}




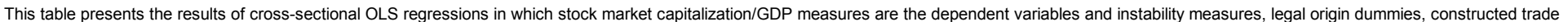

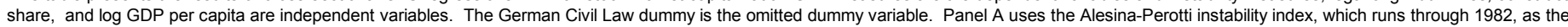

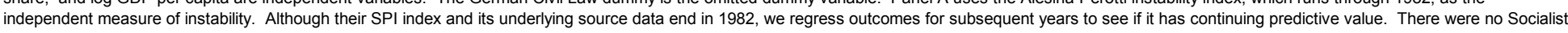

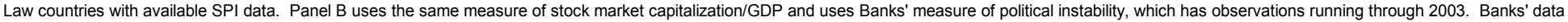
has observations for socialist law countries in most years; for 1983-1991, there were no Socialist Law countries with data on all variables.

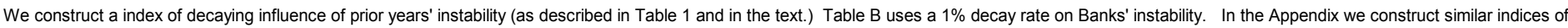

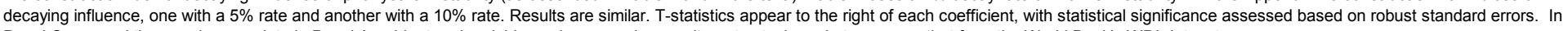
Panel C, we pool the year-by-year data in Panel A, add a trend variable, and re-run using an alternate stock market measure, that from the World Bank's WDI dataset.

Panel A: Stock market capitalization/GDP (via Beck, Demirgüç-Kunt, and Levine's measure) as predicted by political instability (via SPI), legal origin, trade and log GDP per capita

\begin{tabular}{|c|c|c|c|c|c|c|c|c|c|c|c|c|c|c|c|}
\hline Year of Data & SPI Index & & French Civ & I Law & Common Le & & Scandinavi & Civil Law & Constructe & Trade Shar & $\varepsilon \log$ of GDF & per capita & & & \\
\hline & Coefficient & t-statistic & Coefficient & t-statistic & Coefficient & t-statistic & Coefficient & t-statistic & Coefficient & t-statistic & Coefficient & t-statistic & Obs & $p$ value & R-squared \\
\hline 1976 & -0.007 & -0.58 & 0.020 & 0.23 & 0.206 & 1.61 & -0.115 & -1.47 & 0.000 & -0.14 & 0.029 & 0.51 & 17 & 0.056 & 0.431 \\
\hline 1980 & $-0.005^{*}$ & -1.77 & 0.003 & 0.04 & $0.239^{*}$ & 1.95 & -0.111 & -1.50 & -0.002 & -0.94 & $0.061^{\star \star *}$ & 2.88 & 29 & 0.008 & 0.418 \\
\hline 1981 & $-0.005^{*}$ & -1.95 & -0.013 & -0.17 & $0.205^{*}$ & 1.91 & -0.112 & -1.54 & $-0.004^{*}$ & -1.97 & $0.064^{* * *}$ & 3.78 & 36 & 0.001 & 0.423 \\
\hline 1983 & $-0.005^{\star \star}$ & -2.07 & -0.018 & -0.21 & $0.204^{*}$ & 1.90 & -0.099 & -1.12 & -0.002 & -1.12 & $0.067^{\star \star \star}$ & 4.16 & 40 & 0.000 & 0.481 \\
\hline 1984 & $-0.005^{\star \star}$ & -2.23 & -0.055 & -0.59 & 0.165 & 1.47 & -0.105 & -1.12 & $-0.004^{\star *}$ & -2.11 & $0.072^{\star * *}$ & 4.30 & 40 & 0.000 & 0.501 \\
\hline 1985 & $-0.005^{\star *}$ & -2.45 & -0.127 & -1.00 & 0.090 & 0.65 & -0.190 & -1.45 & -0.003 & -1.39 & $0.078^{\star \star *}$ & 4.93 & 40 & 0.000 & 0.520 \\
\hline 1986 & $-0.006^{\star \star \star}$ & -2.98 & -0.155 & -1.05 & 0.094 & 0.59 & -0.240 & -1.54 & $-0.005^{\star}$ & -1.80 & $0.099^{\star \star *}$ & 5.96 & 42 & 0.000 & 0.530 \\
\hline 1987 & $-0.007^{\star \star \star}$ & -3.17 & -0.177 & -1.00 & 0.074 & 0.39 & -0.273 & -1.54 & $-0.006^{*}$ & -1.97 & $0.106^{\star \star *}$ & 5.42 & 44 & 0.000 & 0.519 \\
\hline 1988 & $-0.007^{\star \star \star}$ & -2.94 & -0.219 & -1.07 & 0.012 & 0.05 & -0.260 & -1.30 & $-0.007^{\star}$ & -1.98 & $0.101^{\star \star \star}$ & 4.48 & 43 & 0.000 & 0.465 \\
\hline 1989 & $-0.007^{* *}$ & -2.63 & -0.307 & -1.21 & -0.081 & -0.30 & -0.319 & -1.31 & $-0.008^{*}$ & -1.79 & $0.110^{\star \star *}$ & 4.23 & 43 & 0.000 & 0.474 \\
\hline 1990 & $-0.007^{\star *}$ & -2.27 & -0.244 & -1.14 & -0.026 & -0.11 & -0.269 & -1.34 & $-0.008^{\star}$ & -1.88 & $0.094^{\star \star *}$ & 3.93 & 44 & 0.000 & 0.447 \\
\hline 1991 & $-0.007^{\star \star}$ & -2.42 & -0.129 & -0.79 & 0.088 & 0.47 & -0.194 & -1.22 & $-0.007^{*}$ & -1.98 & $0.086^{\star \star \star}$ & 3.68 & 44 & 0.000 & 0.394 \\
\hline 1992 & $-0.008^{\star * *}$ & -2.23 & -0.078 & -0.50 & 0.170 & 0.98 & -0.206 & -1.35 & $-0.007^{\star \star * *}$ & -3.04 & $0.091^{\star * *}$ & 4.07 & 47 & 0.000 & 0.408 \\
\hline 1993 & -0.009 & -1.56 & -0.045 & -0.23 & 0.298 & 1.28 & -0.191 & -1.03 & $-0.007^{\star}$ & -1.97 & $0.101^{\star \star *}$ & 3.11 & 49 & 0.003 & 0.297 \\
\hline 1994 & -0.012 & -1.58 & -0.026 & -0.12 & 0.297 & 1.12 & -0.164 & -0.81 & $-0.008^{\star \star}$ & -2.13 & $0.091^{* *}$ & 2.38 & 48 & 0.010 & 0.237 \\
\hline 1995 & $-0.009^{*}$ & -1.92 & -0.073 & -0.30 & 0.195 & 0.74 & -0.165 & -0.71 & $-0.009^{\star \star \star}$ & -2.68 & $0.088^{* *}$ & 2.66 & 51 & 0.001 & 0.251 \\
\hline 1996 & $-0.009^{*}$ & -1.84 & -0.072 & -0.25 & 0.206 & 0.66 & -0.158 & -0.55 & $-0.009^{* *}$ & -2.46 & $0.123^{* *}$ & 3.46 & 51 & 0.000 & 0.264 \\
\hline 1997 & $-0.008^{\star * *}$ & -2.04 & -0.129 & -0.34 & 0.135 & 0.35 & -0.131 & -0.33 & $-0.009^{* *}$ & -2.16 & $0.150^{\star \star * *}$ & 4.83 & 53 & 0.000 & 0.356 \\
\hline 2003 & -0.002 & -0.58 & -0.177 & -0.43 & 0.077 & 0.18 & -0.158 & -0.37 & $-0.007^{\star}$ & -1.69 & $0.166^{\star \star * *}$ & 6.16 & 51 & 0.000 & 0.379 \\
\hline
\end{tabular}

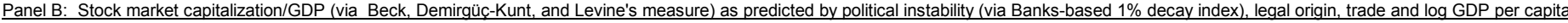

\begin{tabular}{|c|c|c|c|c|c|c|c|c|c|c|c|c|c|c|c|c|c|}
\hline \multirow[t]{2}{*}{ Year of Data } & \multicolumn{2}{|c|}{$\begin{array}{l}\text { One-Percent Thirty- } \\
\text { Year Political Instability } \\
\text { Decay Index }\end{array}$} & \multicolumn{2}{|c|}{ French Civil Law } & \multicolumn{2}{|c|}{ Common Law } & \multicolumn{2}{|c|}{ Scandinavian Civil Law } & \multicolumn{2}{|c|}{ Socialist Law } & \multicolumn{4}{|c|}{ Constructed Trade Share Log of GDP per capita } & \multirow[b]{2}{*}{ Obs } & \multirow[b]{2}{*}{$p$ value } & \multirow[b]{2}{*}{ R-squared } \\
\hline & Coefficient & t-statistic & Coefficient & t-statistic & Coefficient & t-statistic & Coefficient & t-statistic & Coefficient & t-statistic & Coefficient & t-statistic & Coefficient & t-statistic & & & \\
\hline 1983 & $-0.007^{\star \star \star}$ & -2.73 & -0.078 & -0.96 & 0.168 & 1.52 & $-0.177^{\star \star}$ & -2.18 & & & $0.004^{\star \star \star}$ & 14.12 & $0.052^{\star \star \star}$ & 2.89 & 37 & 0.000 & 0.743 \\
\hline 1985 & $-0.008^{*}$ & -2.02 & -0.183 & -1.46 & 0.073 & 0.51 & $-0.306^{\star \star}$ & -2.60 & & & $0.008^{\star \star *}$ & 11.40 & $0.066^{\star \star \star}$ & 3.73 & 37 & 0.000 & 0.847 \\
\hline 1986 & $-0.011^{*}$ & -1.89 & -0.213 & -1.54 & 0.086 & 0.52 & $-0.390^{\star \star *}$ & -2.78 & & & $0.010^{* \star *}$ & 9.72 & $0.088^{\star \star *}$ & 4.38 & 39 & 0.000 & 0.849 \\
\hline 1987 & $-0.013^{\star}$ & -1.81 & -0.259 & -1.31 & 0.049 & 0.22 & $-0.494^{\star \star}$ & -2.33 & & & $0.014^{\star \star \star}$ & 9.04 & $0.088^{\star \star \star}$ & 3.38 & 39 & 0.000 & 0.861 \\
\hline 1988 & -0.013 & -1.62 & -0.362 & -1.53 & -0.074 & -0.27 & $-0.569^{\star \star}$ & -2.19 & & & $0.016^{* \star *}$ & 8.60 & $0.081^{* *}$ & 2.70 & 38 & 0.000 & 0.858 \\
\hline 1990 & $-0.011^{\star *}$ & -2.48 & -0.239 & -1.16 & -0.003 & -0.01 & -0.358 & -1.68 & & & $0.002^{\star \star \star}$ & 2.83 & $0.100^{\star \star \star}$ & 4.37 & 44 & 0.000 & 0.476 \\
\hline 1991 & $-0.013^{\star \star \star}$ & -2.73 & -0.081 & -0.48 & 0.162 & 0.82 & -0.235 & -1.45 & & & $0.001^{* *}$ & 2.67 & $0.092^{\star \star \star}$ & 4.02 & 44 & 0.000 & 0.432 \\
\hline 1992 & $-0.009^{\star \star \star}$ & -3.01 & -0.088 & -0.59 & 0.149 & 0.86 & $-0.258^{*}$ & -1.75 & -0.226 & -1.39 & $0.001^{*}$ & 1.97 & $0.085^{\star \star \star}$ & 4.08 & 51 & 0.000 & 0.412 \\
\hline 1993 & $-0.011^{\star *}$ & -2.24 & -0.085 & -0.50 & 0.292 & 1.29 & -0.245 & -1.49 & -0.244 & -1.30 & $0.002^{* * *}$ & 2.91 & $0.091^{\star * *}$ & 2.83 & 53 & 0.000 & 0.332 \\
\hline 1994 & $-0.012^{\star *}$ & -2.03 & -0.086 & -0.44 & 0.309 & 1.17 & -0.230 & -1.23 & -0.321 & -1.57 & $0.003^{\star \star \star}$ & 3.52 & $0.082^{\star *}$ & 2.32 & 54 & 0.000 & 0.314 \\
\hline 1995 & $-0.012^{\star *}$ & -2.26 & -0.067 & -0.32 & 0.233 & 0.89 & -0.295 & -1.35 & -0.321 & -1.51 & $0.003^{\star * \star}$ & 2.79 & $0.092^{* * *}$ & 3.08 & 59 & 0.000 & 0.325 \\
\hline 1996 & $-0.016^{\star *}$ & -2.40 & -0.029 & -0.11 & 0.277 & 0.90 & -0.267 & -0.99 & -0.263 & -1.01 & $0.003^{* * *}$ & 2.77 & $0.119^{* \star *}$ & 3.76 & 60 & 0.000 & 0.353 \\
\hline 1997 & $-0.012^{\star *}$ & -2.35 & -0.061 & -0.18 & 0.218 & 0.60 & -0.216 & -0.58 & -0.177 & -0.51 & $0.003^{*}$ & 1.78 & $0.162^{\star \star \star}$ & 6.21 & 71 & 0.000 & 0.413 \\
\hline 1998 & $-0.009^{* *}$ & -2.03 & -0.117 & -0.26 & 0.108 & 0.24 & -0.252 & -0.53 & -0.192 & -0.43 & 0.002 & 1.43 & $0.195^{\star * *}$ & 7.02 & 74 & 0.000 & 0.461 \\
\hline 1999 & -0.008 & -1.33 & -0.176 & -0.37 & 0.105 & 0.21 & -0.165 & -0.29 & -0.253 & -0.52 & $0.002^{*}$ & 1.68 & $0.236^{\star \star *}$ & 6.89 & 74 & 0.000 & 0.469 \\
\hline 2001 & -0.007 & -1.22 & -0.128 & -0.25 & 0.110 & 0.21 & -0.045 & -0.08 & -0.210 & -0.41 & 0.001 & 0.86 & $0.226^{\star \star \star}$ & 7.26 & 72 & 0.000 & 0.443 \\
\hline 2002 & -0.008 & -1.47 & -0.093 & -0.25 & 0.106 & 0.28 & -0.114 & -0.28 & -0.224 & -0.60 & 0.000 & 0.35 & $0.163^{\star \star *}$ & 5.56 & 73 & 0.000 & 0.377 \\
\hline 2003 & $-0.011^{\star *}$ & -2.02 & -0.150 & -0.41 & 0.043 & 0.12 & -0.217 & -0.56 & -0.277 & -0.74 & 0.001 & 0.86 & $0.159^{\star \star \star}$ & 6.31 & 68 & 0.000 & 0.417 \\
\hline
\end{tabular}

Panel C: Stock Market Development, the SPI Index, and the Addition of a Trend Variable

This table presents pooled results of the Panel A regression, adding a trend variable, in Model 1. In Model 2, we use an alternate stock market capitalization measure, from the World Bank's WDI dataset. Because the SPI Index is time-invariant, country fixed effects cannot be used. Robust standard errors clustered at the country level are presented below each coefficient in brackets.

DV: Beck et al. Stock Market

DV: WDI Stock Market

Capitalization/GDP (1976-2003) Capitalization/GDP (1988-2004)

\begin{tabular}{lcc}
\hline Independent Variable & Model 1 & Model 2 \\
\hline SPI Index & $-0.006^{* *}$ & $-0.604^{* *}$ \\
& {$[0.003]$} & {$[0.298]$} \\
Constructed Trade Share & $-0.005^{\star}$ & $-0.678^{\star *}$ \\
& {$[0.003]$} & {$[0.330]$} \\
Log of GDP per capita & 0.125 & $15.637^{\star \star \star}$ \\
& {$[0.020]$} & {$[2.384]$} \\
Trend variable included? & Yes & Yes \\
Legal origin included? & Yes & Yes \\
Country fixed effects included? & No & No \\
Obs & 1192 & 811 \\
p-value & 0.000 & 0.000 \\
R-squared & 0.384 & 0.335 \\
\hline
\end{tabular}


Table 5. Changes in Political Instability as Predicting Recent Financial Development

This table presents the results of cross-sectional OLS regressions in which Beck, Demirgüç-Kunt, and Levine's 2000 measure of Stock Market Capitalization/GDP divided by Beck, Demirgüç-Kunt, and Levine's 1990 measure of Stock Market Capitalization/GDP is the dependent variable. The ratio of the (political instability decay index in the year 2000 to its value in the year 1990) minus 1 , is the principal variable of interest. We control for log GDP per capita, trade, and latitude. In a robustness check, we also control for the ratio of log GDP per capita in 2000 to log GDP per capita in 1990. Robust standard errors appear below each coefficient in brackets. ${ }^{* * *}$ means significance at the .01 level, ${ }^{* *}$ means significance at the .05 level, and * means significance at the .10 level.

DV: (Levine Stock Market Capitalization/GDP 2000)/(Levine Stock Market Capitalization/GDP 1990) Independent Variable
Increase in political instability (as measured
by: ((Political instability decay index 2000/ Political instability decay index 1990) - 1) Model 1 Model 2 Model 3 Model 4

Log of GDP per capita 1990

$\begin{array}{rrrr}-1.146 \text { ** } & -1.117^{* *} & -1.1666^{* *} & -1.049 \text { ** } \\ {[0.554]} & {[0.501]} & {[0.542]} & {[0.472]} \\ & -0.247 & & -0.347 \\ & {[0.341]} & & {[0.366]} \\ & -0.009^{*} & -0.009 * & -0.003 \\ & {[0.004]} & {[0.005]} & {[0.005]} \\ & 2.320 & 0.846 & 1.823 \\ & {[3.862]} & {[2.660]} & {[3.759]} \\ & & & \\ & & -7.265 & -17.571 \\ & & {[21.372]} & {[21.252]} \\ & & & 0.147 \\ & & & {[0.060]} \\ 0.045 & & & 44 \\ 0.052 & 44 & 44 & 0.037 \\ & 0.121 & 0.127 & 0.213\end{array}$

$\mathrm{p}$ value

0.052

0.121

R-squared

0.073

0.213 
Table 6. Political Instability, Equity Market Development, and Corporate Law Indices

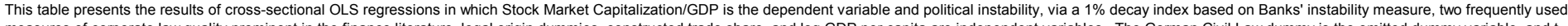

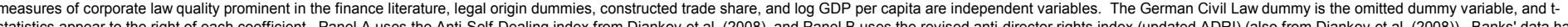

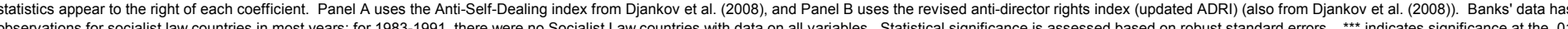
level, ** significance at the 05 level, and * significance at the 1091 , there

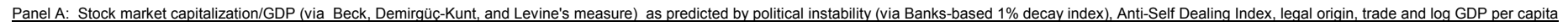

\begin{tabular}{|c|c|c|c|c|c|c|c|c|c|c|c|c|c|c|c|c|c|c|c|}
\hline \multirow[t]{2}{*}{ Year of Data } & \multicolumn{2}{|c|}{$\begin{array}{l}\text { One-Percent Thirty- } \\
\text { Year Political Instability } \\
\text { Decay Index }\end{array}$} & \multicolumn{2}{|c|}{$\begin{array}{l}\text { Anti-Self-Dealing } \\
\text { Index from Djankov et } \\
\text { al. (2008) }\end{array}$} & \multicolumn{2}{|c|}{ French Civil Law } & \multicolumn{2}{|l|}{ Common Law } & \multicolumn{2}{|c|}{ Scandinavian Civil Law } & \multicolumn{2}{|l|}{ Socialist Law } & \multicolumn{2}{|c|}{ Constructed Trade Share } & \multicolumn{2}{|c|}{ Log of GDP per capita } & \multirow[b]{2}{*}{ Obs } & \multirow[b]{2}{*}{$\mathrm{p}$ value } & \multirow[b]{2}{*}{ R-squared } \\
\hline & Coefficient & t-statistic & Coefficient & t-statistic & Coefficient & t-statistic & Coefficient & t-statistic & Coefficient & t-statistic & Coefficient & t-statistic & Coefficient & t-statistic & Coefficient & t-statistic & & & \\
\hline 1983 & $-0.008^{* * *}$ & -2.76 & 0.197 & 1.19 & -0.065 & -0.80 & 0.112 & 1.15 & $-0.180^{* *}$ & -2.14 & & & $0.004^{* * *}$ & 15.57 & $0.052^{* * *}$ & 3.10 & 37 & 0.000 & 0.753 \\
\hline 1984 & $-0.009^{* *}$ & -2.54 & 0.206 & 1.25 & -0.074 & -0.79 & 0.083 & 0.73 & $-0.198^{* *}$ & -2.06 & & & $0.005^{* * *}$ & 11.12 & $0.057^{* * *}$ & 3.60 & 36 & 0.000 & 0.786 \\
\hline 1985 & $-0.010^{* *}$ & -2.15 & 0.191 & 1.21 & -0.159 & -1.24 & 0.015 & 0.10 & $-0.306^{* *}$ & -2.48 & & & $0.008^{* \star *}$ & 11.93 & $0.064^{* * *}$ & 3.70 & 36 & 0.000 & 0.855 \\
\hline 1986 & $-0.013^{*}$ & -2.03 & $0.376^{* *}$ & 2.12 & -0.180 & -1.24 & -0.027 & -0.16 & $-0.391^{* *}$ & -2.59 & & & $0.010^{* * *}$ & 10.57 & $0.080^{* * *}$ & 4.29 & 38 & 0.000 & 0.863 \\
\hline 1987 & $-0.014^{*}$ & -1.86 & $0.520^{* *}$ & 2.32 & -0.248 & -1.27 & -0.115 & -0.52 & $-0.503^{* *}$ & -2.35 & & & $0.014^{* \star *}$ & 9.66 & $0.078^{* * *}$ & 3.21 & 39 & 0.000 & 0.873 \\
\hline 1988 & -0.015 & -1.68 & $0.558^{* *}$ & 2.14 & -0.349 & -1.54 & -0.251 & -0.97 & $-0.579^{* *}$ & -2.29 & & & $0.016^{* * *}$ & 9.11 & $0.069^{* *}$ & 2.48 & 38 & 0.000 & 0.868 \\
\hline 1989 & $-0.014^{*}$ & -1.99 & $0.466^{*}$ & 2.02 & $-0.499^{* *}$ & -2.31 & $-0.418^{*}$ & -1.75 & $-0.681^{1 * * *}$ & -2.86 & & & $0.010^{* * *}$ & 9.57 & $0.090^{* * *}$ & 3.96 & 38 & 0.000 & 0.818 \\
\hline 1990 & $-0.012^{* *}$ & -2.36 & $0.582^{* *}$ & 2.34 & -0.258 & -1.40 & -0.230 & -1.17 & $-0.396^{* *}$ & -2.04 & & & $0.002^{* * *}$ & 4.51 & $0.082^{* * *}$ & 3.49 & 43 & 0.000 & 0.547 \\
\hline 1991 & $-0.015^{* *}$ & -2.54 & $0.569^{* *}$ & 2.14 & -0.098 & -0.67 & -0.062 & -0.38 & $-0.271^{*}$ & -1.84 & & & $0.002^{* * *}$ & 4.27 & $0.072^{* * *}$ & 2.94 & 43 & 0.000 & 0.505 \\
\hline 1992 & $-0.013^{* * *}$ & -2.76 & $0.539^{* *}$ & 2.23 & -0.051 & -0.37 & 0.017 & 0.13 & $-0.294^{* *}$ & -2.16 & $-0.253^{*}$ & -1.85 & $0.002^{* * *}$ & 3.73 & $0.086^{* * *}$ & 3.46 & 47 & 0.000 & 0.544 \\
\hline 1993 & $-0.016^{* *}$ & -2.27 & $0.788^{* *}$ & 2.09 & -0.033 & -0.20 & 0.098 & 0.57 & $-0.298^{*}$ & -1.80 & $-0.298^{*}$ & -1.73 & $0.003^{* \star *}$ & 4.11 & $0.087^{* *}$ & 2.25 & 49 & 0.000 & 0.476 \\
\hline 1994 & $-0.018^{* *}$ & -2.21 & $0.889^{* *}$ & 2.08 & -0.037 & -0.20 & 0.090 & 0.44 & -0.293 & -1.54 & $-0.449^{* *}$ & -2.06 & $0.004^{* * *}$ & 5.91 & $0.074^{*}$ & 1.74 & 50 & 0.000 & 0.459 \\
\hline 1995 & $-0.017^{\star *}$ & -2.49 & $0.820^{* *}$ & 2.30 & -0.043 & -0.20 & -0.006 & -0.03 & -0.322 & -1.47 & $-0.493^{* *}$ & -2.15 & $0.004^{* * *}$ & 5.62 & 0.058 & 1.56 & 53 & 0.000 & 0.461 \\
\hline 1996 & $-0.020^{* *}$ & -2.48 & $0.829^{* *}$ & 2.23 & -0.004 & -0.01 & 0.046 & 0.17 & -0.295 & -1.06 & -0.445 & -1.61 & $0.004^{* * *}$ & 5.34 & $0.090^{* *}$ & 2.27 & 53 & 0.000 & 0.465 \\
\hline 1997 & $-0.017^{* * *}$ & -2.74 & $0.561^{* *}$ & 2.11 & -0.019 & -0.05 & 0.115 & 0.33 & -0.234 & -0.61 & -0.326 & -0.92 & $0.004^{* * *}$ & 4.97 & $0.136^{* * *}$ & 4.02 & 59 & 0.000 & 0.521 \\
\hline 1998 & $-0.015^{* *}$ & -2.50 & $0.373^{*}$ & 1.68 & -0.059 & -0.13 & 0.094 & 0.21 & -0.269 & -0.55 & -0.285 & -0.64 & $0.003^{* * *}$ & 4.79 & $0.185^{* * *}$ & 5.32 & 59 & 0.000 & 0.541 \\
\hline 1999 & $-0.015^{* *}$ & -2.02 & $0.491^{*}$ & 1.79 & -0.111 & -0.23 & 0.009 & 0.02 & -0.183 & -0.31 & -0.382 & -0.81 & $0.003^{* * *}$ & 3.57 & $0.219^{* * *}$ & 5.17 & 59 & 0.000 & 0.496 \\
\hline 2000 & $-0.014^{*}$ & -1.71 & 0.494 & 1.62 & -0.135 & -0.23 & -0.025 & -0.04 & -0.076 & -0.10 & -0.423 & -0.75 & $0.002^{* * *}$ & 2.80 & $0.242^{* * *}$ & 5.35 & 59 & 0.000 & 0.456 \\
\hline 2001 & $-0.013^{*}$ & -1.87 & 0.436 & 1.66 & -0.095 & -0.19 & 0.047 & 0.10 & -0.063 & -0.10 & -0.338 & -0.67 & $0.002^{* *}$ & 2.61 & $0.207^{* * *}$ & 5.48 & 59 & 0.000 & 0.470 \\
\hline 2002 & $-0.013^{*}$ & -2.00 & 0.266 & 1.16 & -0.080 & -0.22 & 0.110 & 0.31 & -0.130 & -0.32 & -0.321 & -0.89 & $0.001^{* *}$ & 2.25 & $0.144^{* * *}$ & 3.95 & 59 & 0.000 & 0.417 \\
\hline 2003 & $-0.015^{* *}$ & -2.49 & 0.332 & 1.58 & -0.150 & -0.41 & 0.018 & 0.05 & -0.236 & -0.60 & -0.379 & -1.04 & $0.002^{* * *}$ & 2.88 & $0.138^{* * *}$ & 4.68 & 58 & 0.000 & 0.498 \\
\hline
\end{tabular}

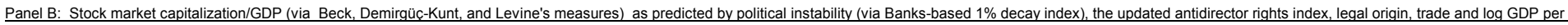

\begin{tabular}{|c|c|c|c|c|c|c|c|c|c|c|c|c|c|c|c|c|c|c|c|}
\hline \multirow[t]{2}{*}{ Year of Data } & \multicolumn{2}{|c|}{$\begin{array}{l}\text { One-Percent Thirty- } \\
\text { Year Political Instability } \\
\text { Decay Index }\end{array}$} & \multicolumn{2}{|c|}{$\begin{array}{l}\text { Revised ADRI (from } \\
\text { Djankov et al. (2008)) }\end{array}$} & \multicolumn{2}{|c|}{ French Civil Law } & \multicolumn{2}{|c|}{ Common Law } & \multicolumn{2}{|c|}{ Scandinavian Civil Law } & \multicolumn{2}{|c|}{ Socialist Law } & \multicolumn{2}{|c|}{ Constructed Trade Share } & \multicolumn{2}{|c|}{ Log of GDP per capita } & \multirow[b]{2}{*}{ Obs } & \multirow[b]{2}{*}{$p$ value } & \multirow[b]{2}{*}{ R-squared } \\
\hline & Coefficient & t t-statistic & Coefficien & t t-statistic & Coefficient & t t-statistic & Coefficien & t t-statistic & Coefficient & t-statistic & Coefficient & t-statistic & Coefficient & t-statistic & Coefficien & it t-statistic & & & \\
\hline 1983 & $-0.007^{* \star}$ & -2.59 & 0.031 & 1.19 & -0.051 & -0.60 & 0.148 & 1.44 & $-0.187^{* \star}$ & -2.26 & & & $0.004^{* * *}$ & 17.88 & $0.055^{* * *}$ & 2.90 & 37 & 0.000 & 0.753 \\
\hline 1984 & $-0.009^{* *}$ & -2.35 & 0.042 & 1.36 & -0.058 & -0.60 & 0.112 & 0.97 & $-0.209^{* *}$ & -2.17 & & & $0.005^{* * *}$ & 11.37 & $0.061^{* * *}$ & 3.43 & 36 & 0.000 & 0.790 \\
\hline 1985 & $-0.010^{*}$ & -2.02 & $0.076^{\star \star}$ & 2.31 & -0.121 & -0.95 & 0.025 & 0.18 & $-0.329^{* *}$ & -2.73 & & & $0.008^{* \star *}$ & 13.16 & $0.073^{* * *}$ & 4.24 & 36 & 0.000 & 0.871 \\
\hline 1986 & $-0.014^{*}$ & -1.97 & $0.088^{* *}$ & 2.55 & -0.120 & -0.86 & 0.036 & 0.24 & $-0.414^{* * *}$ & -2.89 & & & $0.011^{* * *}$ & 11.42 & $0.097^{\star * *}$ & 5.27 & 38 & 0.000 & 0.873 \\
\hline 1987 & $-0.014^{*}$ & -1.78 & 0.101 & 2.38 & -0.182 & -0.92 & -0.019 & -0.09 & $-0.529^{* *}$ & -2.45 & & & $0.015^{* \star *}$ & 10.07 & $0.096^{* * *}$ & 3.86 & 39 & 0.000 & 0.877 \\
\hline 1988 & -0.014 & -1.64 & $0.114^{* *}$ & 2.33 & -0.272 & -1.16 & -0.152 & -0.58 & $-0.608^{* *}$ & -2.32 & & & $0.017^{* \star *}$ & 9.47 & $0.089^{* * *}$ & 3.10 & 38 & 0.000 & 0.873 \\
\hline 1989 & $-0.014^{*}$ & -1.99 & $0.100^{* \star *}$ & 2.82 & $-0.428^{*}$ & -1.92 & -0.338 & -1.39 & $-0.705^{* * *}$ & -2.90 & & & $0.010^{* * *}$ & 10.14 & $0.107^{* * *}$ & 4.93 & 38 & 0.000 & 0.828 \\
\hline 1990 & $-0.012^{* *}$ & -2.36 & $0.080^{* *}$ & 2.03 & -0.193 & -0.96 & -0.075 & -0.36 & $-0.399^{*}$ & -1.95 & & & $0.002^{* * *}$ & 4.39 & $0.104^{* * *}$ & 4.45 & 43 & 0.000 & 0.516 \\
\hline 1991 & $-0.014^{\star *}$ & -2.59 & $0.078^{*}$ & 1.85 & -0.033 & -0.20 & 0.091 & 0.52 & $-0.274^{*}$ & -1.80 & & & $0.002^{* * *}$ & 4.08 & $0.094^{* * *}$ & 3.96 & 43 & 0.000 & 0.474 \\
\hline 1992 & $-0.012^{\star \star *}$ & -2.92 & 0.064 & 1.57 & -0.013 & -0.09 & 0.155 & 0.99 & $-0.289^{* *}$ & -2.08 & -0.092 & -0.47 & $0.002^{* * *}$ & 3.88 & $0.098^{\star * *}$ & 3.91 & 47 & 0.000 & 0.494 \\
\hline 1993 & $-0.015^{\star *}$ & -2.34 & $0.101^{*}$ & 1.70 & 0.030 & 0.18 & 0.301 & 1.49 & $-0.295^{*}$ & -1.89 & -0.039 & -0.17 & $0.003^{* * *}$ & 4.50 & $0.110^{* * *}$ & 2.85 & 49 & 0.000 & 0.427 \\
\hline 1994 & $-0.017^{* *}$ & -2.21 & $0.119^{*}$ & 1.93 & 0.043 & 0.22 & 0.318 & 1.34 & -0.292 & -1.62 & -0.161 & -0.66 & $0.004^{* \star *}$ & 5.93 & $0.102^{* *}$ & 2.40 & 50 & 0.000 & 0.419 \\
\hline 1995 & $-0.016^{* *}$ & -2.46 & $0.090^{*}$ & 1.94 & 0.014 & 0.06 & 0.229 & 0.93 & -0.358 & -1.60 & -0.305 & -1.29 & $0.004^{* * *}$ & 5.05 & $0.084^{* *}$ & 2.34 & 53 & 0.000 & 0.414 \\
\hline 1996 & $-0.018^{* *}$ & -2.43 & $0.085^{*}$ & 1.79 & 0.053 & 0.20 & 0.291 & 0.99 & -0.327 & -1.18 & -0.256 & -0.91 & $0.004^{* * *}$ & 4.64 & $0.117^{* * *}$ & 3.03 & 53 & 0.000 & 0.421 \\
\hline 1997 & $-0.017^{* * *}$ & -2.78 & $0.072^{*}$ & 1.73 & 0.056 & 0.16 & 0.260 & 0.73 & -0.268 & -0.70 & -0.171 & -0.47 & $0.004^{* * *}$ & 4.78 & $0.164^{* * *}$ & 5.65 & 59 & 0.000 & 0.499 \\
\hline 1998 & $-0.015^{* *}$ & -2.53 & 0.046 & 1.20 & -0.011 & -0.02 & 0.192 & 0.43 & -0.291 & -0.60 & -0.184 & -0.40 & $0.003^{* * *}$ & 4.47 & $0.202^{* * *}$ & 6.82 & 59 & 0.000 & 0.531 \\
\hline 1999 & $-0.015^{* *}$ & -2.01 & 0.061 & 1.28 & -0.045 & -0.09 & 0.139 & 0.28 & -0.212 & -0.36 & -0.249 & -0.50 & $0.003^{* * *}$ & 3.19 & $0.242^{* * *}$ & 6.42 & 59 & 0.000 & 0.483 \\
\hline 2000 & $-0.013^{*}$ & -1.71 & 0.069 & 1.30 & -0.065 & -0.11 & 0.098 & 0.17 & -0.110 & -0.15 & -0.287 & -0.48 & $0.002^{* *}$ & 2.52 & $0.266^{* * *}$ & 6.75 & 59 & 0.000 & 0.448 \\
\hline 2001 & $-0.013^{*}$ & -1.84 & 0.064 & 1.37 & -0.032 & -0.06 & 0.151 & 0.29 & -0.095 & -0.16 & -0.217 & -0.41 & $0.002^{* *}$ & 2.28 & $0.228^{* * *}$ & 6.81 & 59 & 0.000 & 0.462 \\
\hline 2002 & $-0.013^{*}$ & -1.97 & 0.049 & 1.30 & -0.035 & -0.10 & 0.164 & 0.44 & -0.156 & -0.38 & -0.245 & -0.64 & $0.001^{* *}$ & 2.10 & $0.157^{\star * *}$ & 4.21 & 59 & 0.000 & 0.416 \\
\hline 2003 & $-0.015^{* *}$ & -2.44 & 0.055 & 1.46 & -0.098 & -0.27 & 0.092 & 0.25 & -0.264 & -0.68 & -0.288 & -0.75 & $0.002^{* * *}$ & 2.72 & $0.153^{* * *}$ & 5.51 & 58 & 0.000 & 0.494 \\
\hline
\end{tabular}




\section{Table 7. Country Fixed Effects}

This table presents the results of panel regressions with country-level fixed effects and year dummies. The dependent variable in in the first model is the World Bank's measure of stock market capitalization to GDP. In the second model the dependent variable is Beck, Demirgüç-Kunt, and Levine's Stock Market Capitalization/ GDP (1976-2003). We use the Banks-based index of political instability, with the index decaying, as described in Table 1 and in the paper's text. The instability measure is significant in both country fixed effects models.

Robust standard errors appear below each coefficient in brackets. Note: ${ }^{* * *}$ means significance at the .01 level, ${ }^{* *}$ means significance at the .05 level, and * means significance at the .10 level. The data from Banks is available until 2003. The stock market data is available back to 1988 in model 1 and back to 1976 in Model 2. Hence, the models account for all available data. In each model we use year dummies and country fixed effects.

\section{DV: Stock Market} Capitalization/GDP (1988-2003)

Independent Variable

One Percent Political Instability Decay Index

Log GDP per capita

Obs

Number of countries

Country fixed effects included

Year fixed effects included

$p$ value

R-squared (within)
DV: Beck, Demirgüç-Kunt, and Levine's Stock Market Capitalization/ GDP (19762003)

Model 1

$-2.725^{* * \times}$

[0.562]

11.906

[10.683]

996

85

Yes

Yes

0.000

0.191
Model 2

$-0.007^{\text {** }}$

[0.003]

0.124 *

[0.068]

1311

81

Yes

Yes

0.000

0.323 


\section{Table 8. Alternative Indicator for External Market Capitalization}

This table presents the results of cross-sectional OLS regressions using La Porta et al.'s (2006) measures of external market capitalization. Model 1 uses the SPI index, which runs until 1982, to measure instability; Model 2 uses the Banks data (in a decay index described in Table 1), which run until 2003. Instability is significant in both models. Robust standard errors appear below each coefficient in brackets. ${ }^{* * *}$ indicates significance at the .01 level, ${ }^{* *}$ significance at the .05 level, and * significance at the .10 level.

\begin{tabular}{lcc} 
& $\begin{array}{l}\text { DV: (External Market } \\
\text { Capitalization/GDP) } \\
\text { average for Years } \\
1996-2000 \text { from La } \\
\text { Porta et al. (2006) }\end{array}$ & $\begin{array}{l}\text { DV: (External Market } \\
\text { Capitalization/GDP) } \\
\text { average for Years } \\
1996-2000 \text { from La } \\
\text { Porta et al. (2006) }\end{array}$ \\
\hline Independent Variable & Model 1 & Model 2 \\
\hline SPI Index & $-0.007^{* *}$ & \\
One Percent Political Instability Decay Index & {$[0.003]$} & $-0.015 * *$ \\
& & {$[0.006]$} \\
French Civil Law & -0.084 & -0.047 \\
& {$[0.289]$} & {$[0.256]$} \\
German Civil Law & 0.127 & 0.162 \\
& {$[0.296]$} & {$[0.268]$} \\
Scandinavian Civil Law & 0.017 & -0.019 \\
& {$[0.337]$} & {$[0.321]$} \\
Constructed Trade Share & -0.005 & -0.001 \\
& {$[0.005]$} & {$[0.003]$} \\
Log GDP per capita & $0.143{ }^{* * *}$ & $0.156{ }^{* * *}$ \\
Number of countries & {$[0.035]$} & {$[0.032]$} \\
p value & 41 & 43 \\
R-squared (within) & 0.000 & 0.001 \\
\hline
\end{tabular}




\section{Table 9. Political Instability, Income Inequality, and Agricultural Conditions}

This table presents the results of an OLS regressions in which the SPI Index is the dependent variable and the size of the middle class, ethnic fractionalization, Frankema's measure of land inequality, geographic attractiveness for different cash crops, extreme mean temperature, and legal origin serve as independent variables. For the size of the middle class, we use Perotti's (1996) measure of the size of the middle class (third and fourth quintiles) as a percentage of national income. Robust standard errors appear below the coefficients. ${ }^{* \star}{ }^{*}$ indicates significance at the .01 level, ${ }^{*}$ significance at the .05 level, and ${ }^{*}$ significance at the .10 level.

\begin{tabular}{|c|c|c|c|c|c|c|}
\hline & DV: Political Insta & & & & & \\
\hline Independent Variable & (1) & $(2)$ & (3) & $(4)$ & $(5)$ & $(6)$ \\
\hline Size of the Middle Class & $\begin{array}{c}-108.0611^{* * *} \\
{[24.891]}\end{array}$ & $\begin{array}{l}-80.645^{* * *} \\
{[26.863]}\end{array}$ & $\begin{array}{c}-102.295^{* * *} \\
{[31.007]}\end{array}$ & $\begin{array}{c}-107.0744^{\star * *} \\
{[34.481]}\end{array}$ & $\begin{array}{l}-90.800^{* * *} \\
{[23.386]}\end{array}$ & $\begin{array}{c}-126.322 \text { *** } \\
{[28.466]}\end{array}$ \\
\hline Ethnic fractionalization & & $\begin{array}{l}12.608 \text { ** } \\
{[5.900]}\end{array}$ & $\begin{array}{l}-0.123 \\
{[4.110]}\end{array}$ & $\begin{array}{r}2.238 \\
{[5.305]}\end{array}$ & $\begin{array}{l}-2.873 \\
{[4.273]}\end{array}$ & $\begin{array}{l}-3.878 \\
{[4.007]}\end{array}$ \\
\hline Frankema land inequality (theil) & & & $\begin{array}{l}13.831 \text { * } \\
{[8.019]}\end{array}$ & $\begin{array}{l}11.452 \\
{[7.198]}\end{array}$ & $\begin{array}{l}10.174 \\
{[6.234]}\end{array}$ & $\begin{array}{l}14.751 \text { ** } \\
{[6.996]}\end{array}$ \\
\hline Rice export/total agricultural exports in 1975 & & & $\begin{array}{l}26.6677^{\star *} \\
{[12.541]}\end{array}$ & $\begin{array}{l}22.011 \text { ** } \\
{[8.802]}\end{array}$ & $\begin{array}{l}25.108 \text { ** } \\
{[11.411]}\end{array}$ & $\begin{array}{l}25.316 \text { ** } \\
{[11.617]}\end{array}$ \\
\hline Sugar export/total agricultural exports in 1975 & & & $\begin{array}{l}-9.945 \\
{[7.164]}\end{array}$ & $\begin{array}{r}-11.607 \\
{[8.328]}\end{array}$ & $\begin{array}{c}-8.826 \\
{[7.661]}\end{array}$ & $\begin{array}{r}-12.105 \\
{[8.218]}\end{array}$ \\
\hline Cocoa bean plus cocoa powder export/total agriculural exports in 1975 & & & $\begin{array}{l}31.541^{* * *} \\
{[9.157]}\end{array}$ & & $\begin{array}{l}24.859 \text { *** } \\
{[6.594]}\end{array}$ & $\begin{array}{l}36.494 \text { *** } \\
{[7.548]}\end{array}$ \\
\hline Coffee export/total agricultural exports in 1975 & & & $\begin{array}{l}-30.397 \text { ** } \\
{[13.242]}\end{array}$ & $\begin{array}{l}-18.093 \\
{[13.176]}\end{array}$ & & $\begin{array}{l}-30.762 \text { ** } \\
{[13.334]}\end{array}$ \\
\hline Tobacco export/total agricultural exports in 1975 & & & $\begin{array}{r}-4.290 \\
{[11.215]}\end{array}$ & $\begin{array}{l}-10.773 \\
{[14.051]}\end{array}$ & $\begin{array}{r}0.223 \\
{[12.278]}\end{array}$ & $\begin{array}{r}-6.913 \\
{[13.601]}\end{array}$ \\
\hline Mean temperature above 32 degrees Celsius & & & $\begin{array}{l}12.911^{* * *} \\
{[3.137]}\end{array}$ & $\begin{array}{l}10.3222^{* \star *} \\
{[2.929]}\end{array}$ & $\begin{array}{l}10.360^{* * *} \\
{[3.281]}\end{array}$ & $\begin{array}{l}12.5611^{* * *} \\
{[2.818]}\end{array}$ \\
\hline French Civil Law & & & $\begin{array}{r}3.923 \\
{[2.584]}\end{array}$ & & & \\
\hline Common Law & & & $\begin{array}{l}-1.490 \\
{[2.263]}\end{array}$ & & & \\
\hline Scandinavian Civil Law & & & $\begin{array}{r}1.702 \\
{[1.308]}\end{array}$ & & & \\
\hline Obs & 64 & 64 & 53 & 53 & 53 & 53 \\
\hline p value & 0.000 & 0.000 & 0.000 & 0.000 & 0.000 & 0.000 \\
\hline R-squared & 0.221 & 0.276 & 0.618 & 0.465 & 0.490 & 0.575 \\
\hline
\end{tabular}

Note: land inequality comes from Frankema (2006); mean temperature above 32 degrees Celsius comes from Van de Viliert (1999), and crop data comes from FAO Trade Yearbook (1977). 
Panel A. In this table we present a two-stage least squares models with the instruments for political instability from Model 6 of Table 8 . The financial development outcomes are the dependent variables and the instrumented political instability index (again, using Model 6 of Table 9), legal origin dummies, constructed trade share, and log GDP per capita are the independent variables. For the first model, where we look at multiple years of financial development, we control for the start-of-period (Year 1965) Log of GDP per capita. Robust standard errors appear below the coefficients. *** indicates significance at the .01 level, ** significance at the .05 level, and * significance at the .10 level.

\begin{tabular}{|c|c|c|c|c|c|c|}
\hline & $\begin{array}{l}\text { DV: Average of Bank } \\
\text { Loans/GDP for Years 1965- } \\
1982\end{array}$ & $\begin{array}{l}\text { DV: Bank Loans/GDP for Year } \\
1965\end{array}$ & $\begin{array}{l}\text { DV: Bank Loans/GDP for } \\
\text { Year } 1970\end{array}$ & $\begin{array}{l}\text { DV: Bank Loans/GDP for } \\
\text { Year } 1975\end{array}$ & $\begin{array}{l}\text { DV: Stock Market } \\
\text { Capitalization/GDP for Year } \\
1988\end{array}$ & $\begin{array}{l}\text { DV: Beck, Demirgüc-Kunt, } \\
\text { and Levine's Stock Market } \\
\text { Capitalization/GDP for Year } \\
1988\end{array}$ \\
\hline \multicolumn{7}{|c|}{1965} \\
\hline Instrumented SPI Index & $-0.773^{*}$ & $-0.971^{* * *}$ & -0.902 * & $-0.983^{* *}$ & $-1.435^{* *}$ & $-0.015^{* *}$ \\
\hline \multirow{2}{*}{ French Civil Law } & $\begin{array}{l}{[-3.398]} \\
-40.135 \text { ** }\end{array}$ & $\begin{array}{l}{[0.374]} \\
-29.776\end{array}$ & $\begin{array}{l}{[0.466]} \\
-40.184 \text { ** }\end{array}$ & $\begin{array}{r}{[0.471]} \\
-22.915\end{array}$ & $\begin{array}{l}{[0.588]} \\
-22.272\end{array}$ & {$[0.006]$} \\
\hline & [17.391] & {$[15.716]$} & [17.144] & {$[18.293]$} & [21.225] & {$[0.186]$} \\
\hline \multirow{2}{*}{ Common Law } & -44.714 ** & -35.317 ** & $-45.540^{* * *}$ & -28.180 & -7.285 & 0.004 \\
\hline & {$[18.151]$} & {$[15.069]$} & [16.567] & {$[18.846]$} & {$[22.751]$} & {$[0.204]$} \\
\hline \multirow[t]{2}{*}{ Scandinavian Civil Law } & -43.932 ** & $-27.440^{*}$ & -38.796 ** & -34.065 * & -27.084 & -0.260 \\
\hline & [17.557] & [15.111] & [16.775] & [18.397] & [20.693] & {$[0.179]$} \\
\hline Constructed Trade Share & $\begin{array}{l}-0.243 \\
-0.275\end{array}$ & -0.433 *** & -0.399 ** & -0.091 & $-1.045 * \star \star$ & -0.009 ** \\
\hline \multirow[t]{2}{*}{ Log GDP Per Capita } & $7.271_{* * *}$ & $\begin{array}{l}{[0.154]} \\
6.191 * *\end{array}$ & $\begin{array}{l}{[0.196]} \\
7.450 * * *\end{array}$ & $\begin{array}{l}{[0.300]} \\
8.066 * * *\end{array}$ & $\begin{array}{l}{[0.396]} \\
9.460 * *\end{array}$ & $\begin{array}{c}{[0.004]} \\
0.089 * *\end{array}$ \\
\hline & {$[2.251]$} & {$[2.055]$} & {$[2.073]$} & {$[2.178]$} & {$[2.689]$} & {$[0.028]$} \\
\hline Obs & 44 & 44 & 47 & 51 & 35 & 36 \\
\hline F-test, first stage & 28.55 & 28.55 & 22.97 & 15.65 & 43.74 & 47.68 \\
\hline p value & 0.000 & 0.000 & 0.000 & 0.000 & 0.000 & 0.000 \\
\hline R-squared & 0.597 & 0.590 & 0.608 & 0.495 & 0.461 & 0.406 \\
\hline
\end{tabular}

Panel B. In this table we present a two-stage least squares models with the instruments for political instability from Model 6 of Table 8. The financial development outcomes are the dependent variables and the instrumented IMD Perceived Political Stability Index (again, using instruments from Model 6 of Table 8), legal origin dummies, constructed trade share, and start

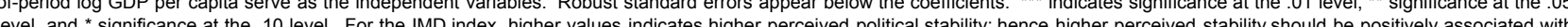
stronger financial development, as it is, at the .01 level.

\begin{tabular}{|c|c|c|c|c|c|c|c|}
\hline \multirow[t]{2}{*}{ Year of Data } & \multirow[t]{2}{*}{ Dependent Variable Used } & \multicolumn{2}{|c|}{$\begin{array}{l}\text { Using Instrumental Variables } \\
\text { from Column (6) of Table } 8 \text { to } \\
\text { Predict Perceived Political } \\
\text { Stability }\end{array}$} & \multirow[t]{2}{*}{$\begin{array}{l}\text { Other Control Variables } \\
\text { (legal origin dummies, } \\
\text { constructed trade share, } \\
\text { and log GDP per capita) } \\
\text { included }\end{array}$} & \multirow[b]{2}{*}{ Obs } & \multirow[b]{2}{*}{ p value } & \multirow[b]{2}{*}{ R-squared } \\
\hline & & Coefficient & t-statistic & & & & \\
\hline & $\begin{array}{l}\text { Stock Market } \\
\text { Capitalization/GDP from Beck }\end{array}$ & & & & & & \\
\hline Average of $1999-2003$ & & $0.147^{\star \star \star}$ & 3.25 & Yes & 30 & 0.001 & 0.335 \\
\hline Average of 1999-2004 & Bank Credit/GDP & $12.072^{\star \star \star}$ & 3.93 & Yes & 30 & 0.000 & 0.645 \\
\hline
\end{tabular}

We used the "estat overid" command in STATA after running two-stage least squares models through Panels A and B of Table 9. In the first model of Panel A, the resulting chi-square is 10.2252 ( $p=0.2496$ ). In the second model of Panel A, the result chi-square is $5.70686(p=0.6800)$. In the third model of Panel A, the resulting chi-square is $7.35047(p=0.4993)$. In the fourth model of Panel A, the resulting chisquare is $4.01532(p=0.855)$. In the fifth model of Panel A, the resulting chi-square is $7.49792(p=0.4840)$. In the sixth model of Panel A, the result chi-square is $5.99024 \quad(p=0.6483)$. In Model 1 of Panel

Using the "estat firststage" command in STATA, we find that the instruments are particularly strong for explaining the stock market development results in Model 5 of Panel A (F-statistic $=17.70$; $\mathrm{p}=0.000$ ); Model 6 of Panel A (F-statistic of 16.67; p = 0.000); and Model 1 of Panel B (F-statistic of 105.40; $p=0.000$ ); and the debt market development results in Model 2 of Panel B (130.86; $p=0.000)$. The firststage F-statistics for the earlier Model $1-4$ of Panel are somewhat weaker: the $R^{2}$ in the first stage for those models is relatively high (greater than 0.46 ), but the $F$ statistics do not surpass the usual rule of thumb of 10. Finally, the results of the post-estimation "sstat endogenous" tests in STATA for every model of Table 9 suggest that political instability can in fact be treated as largely exogenous. Only in Models 5 and 6 of Panel A are the p values for the robust score chi-square below 0.10, and even in those two models the p values are not less than 0.05 . In all other models the p values are between 0.26 and 0.91 . 
Figure 1. Financial Development and Political Instability, Basic Relationship without Controls.
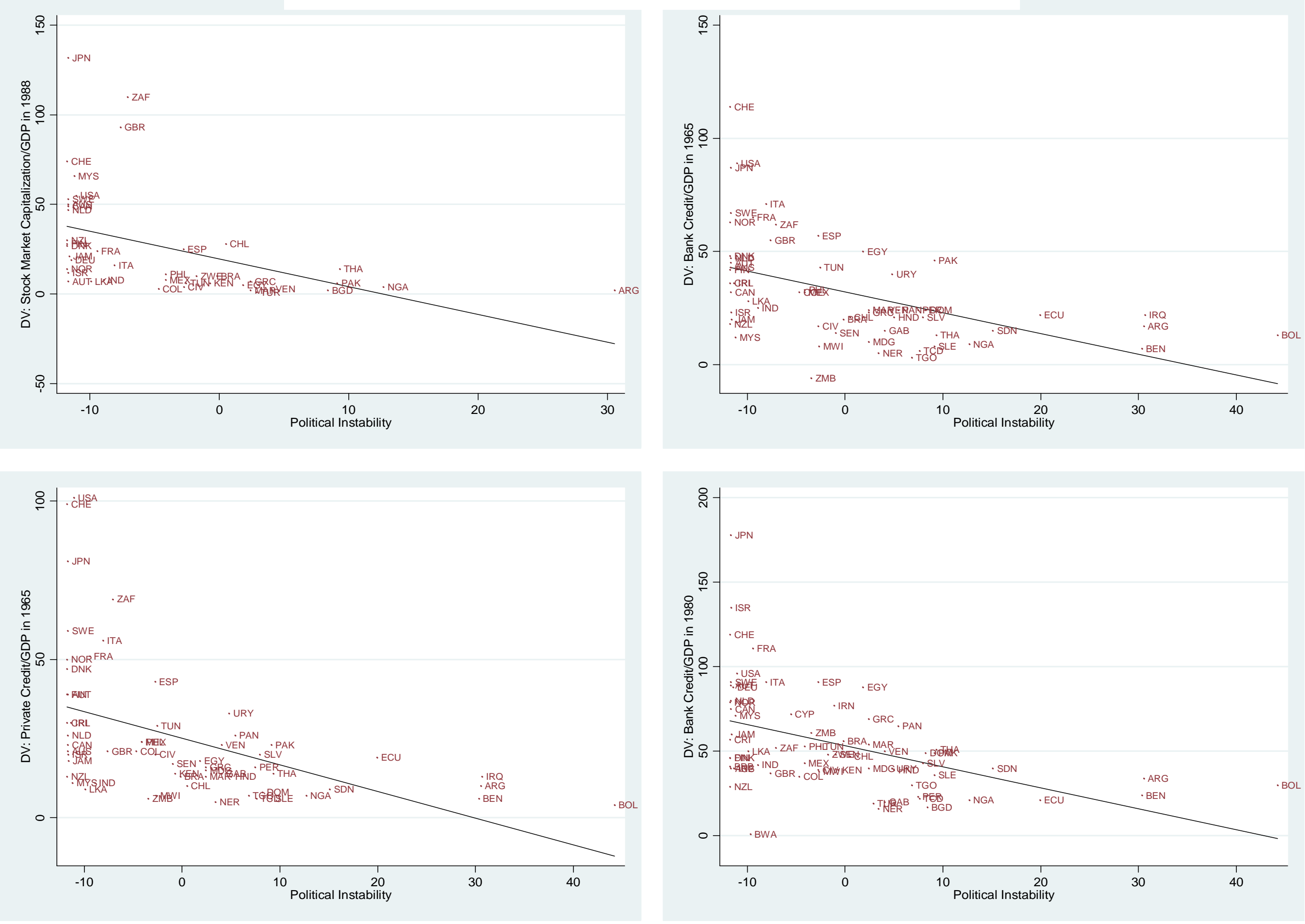
Figure 2. Possible Channels to Financial Backwardness.

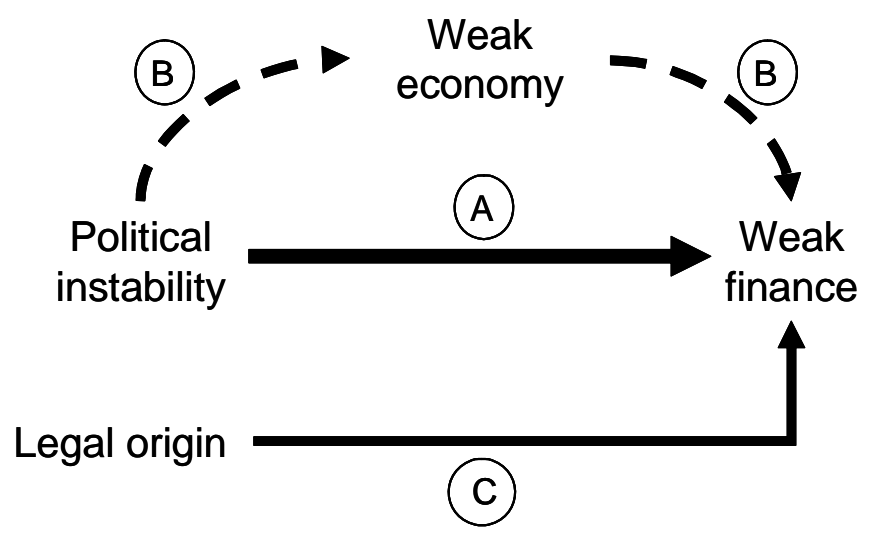

Figure 3. Interactions Between Political Instability and Institutional Quality.

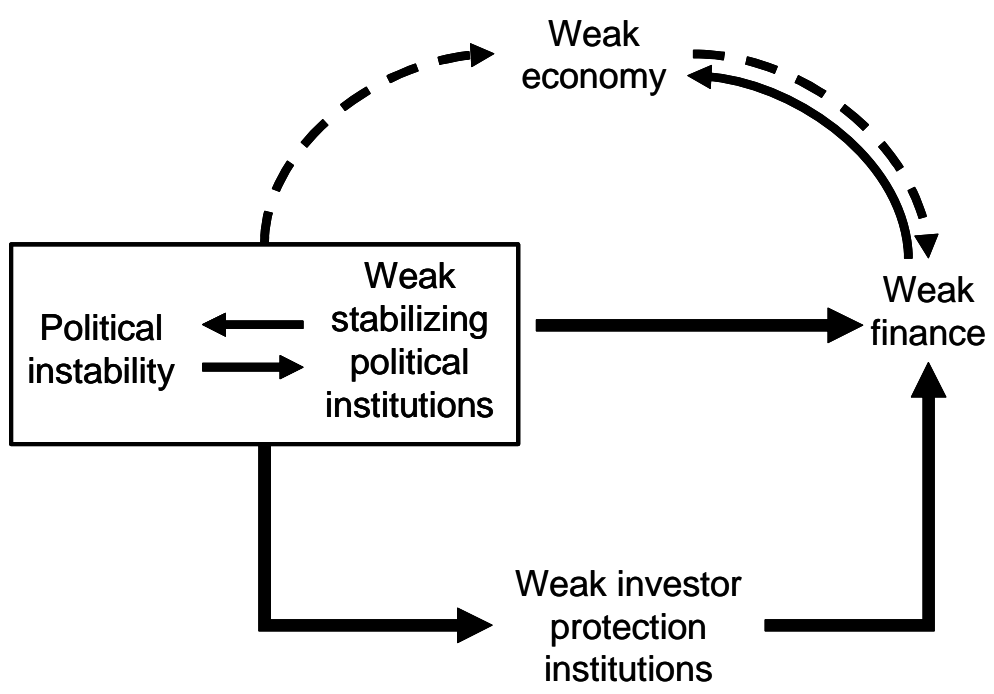




\section{Figure 4: Global Trends in Violent Conflict, 1946-2004.}

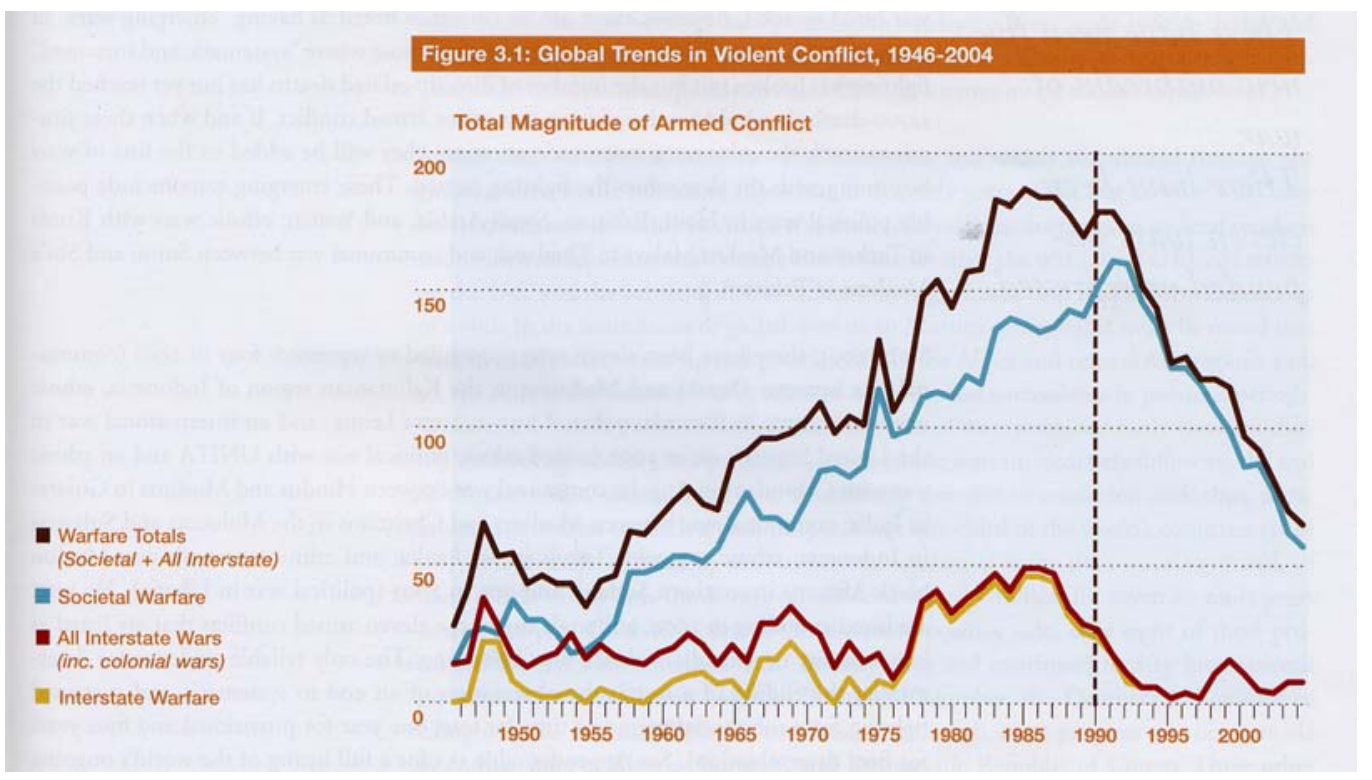

Monty G. Marshall and Ted Robert Gurr. Peace and Conflict 2005: A Global Survey of Armed Conflicts, SelfDetermination Movements, and Democracy. College Park: University of Maryland, Center for International Development and Conflict Management, 2005. Reproduced with permission. 


\section{Figure 5: Incidence and Prevalence of Political Instability Worldwide, 1955-2003.}

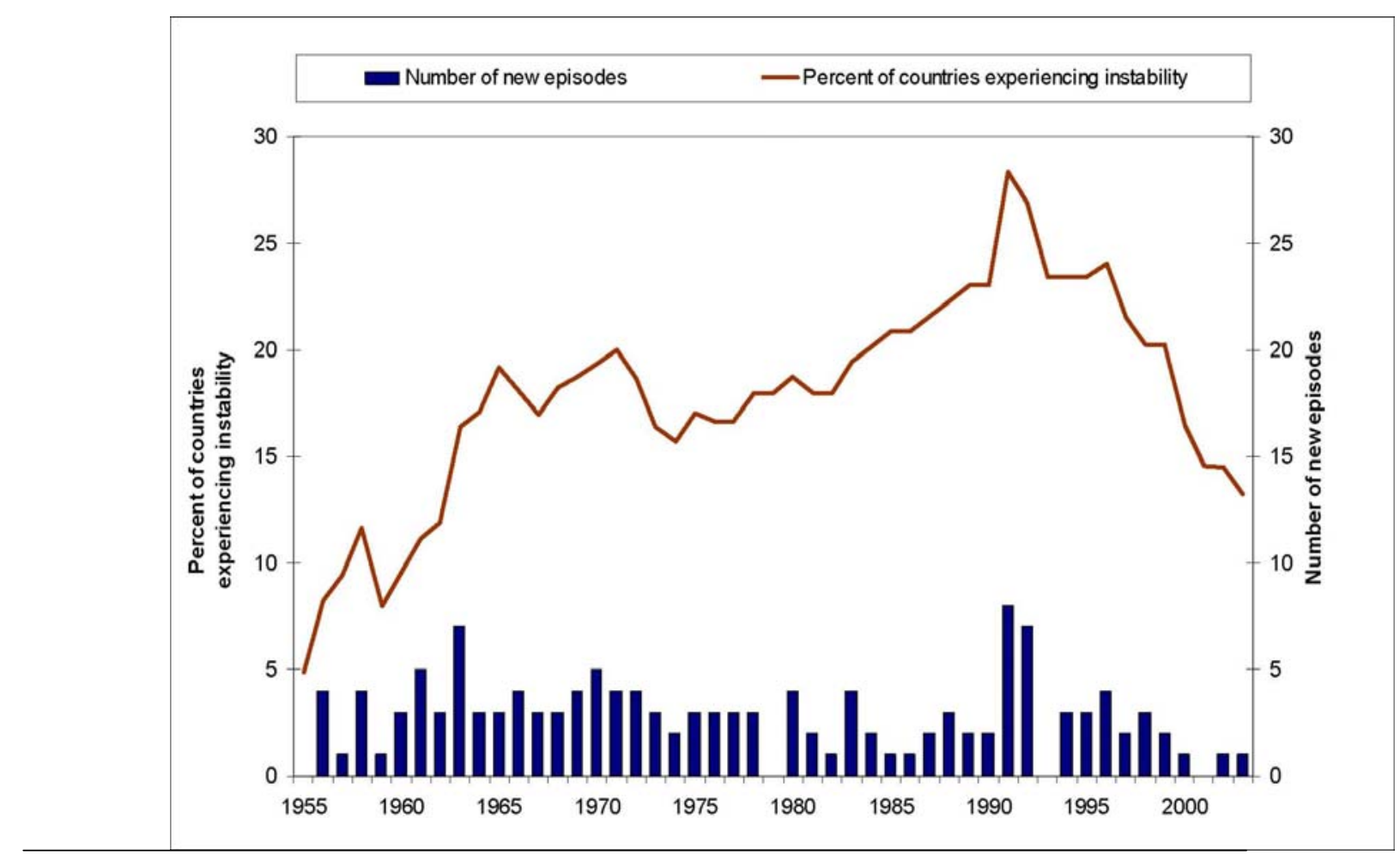

Jack A. Goldstone, Robert H. Bates, Ted Robert Gurr, Michael Lustik, Monty G. Marshall, Jay Ulfelder, and Mark Woodward, A Global Forecasting Model of Political Instability, paper prepared for the Annual Meeting of American Political Science Association, Washington, DC, September 1-4, 2005. Reproduced with permission. 
Figure 6. Possible Channels to and from Financial Backwardness.

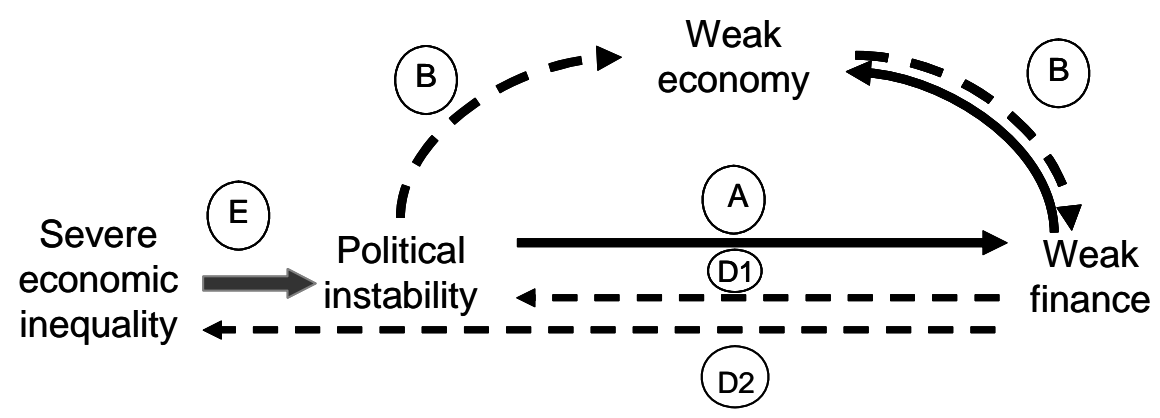

